\title{
Polysaccharides in Agro-Industrial Biomass Residues
}

\author{
Márcio Araújo de Souza ${ }^{1}{ }^{10}$, Isis Tavares Vilas-Boas ${ }^{1}$, Jôse Maria Leite-da-Silva ${ }^{1}$, Pérsia do Nascimento Abrahão ${ }^{1}$, \\ Barbara E. Teixeira-Costa ${ }^{2}$ and Valdir F. Veiga-Junior ${ }^{1, *(\mathbb{D})}$
}

1 Chemistry Section, Military Institute of Engineering (IME), Praça Gen. Tibúrcio, 80, Praia Vermelha, Urca, Rio de Janeiro 22290-270, RJ, Brazil; marcimaraujodesouza@ime.eb.br (M.A.d.S.); itvilasb@gmail.com (I.T.V.-B.); cjosy010@gmail.com (J.M.L.-d.-S.); persia_abrahao@yahoo.com.br (P.d.N.A.)

2 Faculty of Agrarian Sciences, Federal University of Amazonas (UFAM), Avenida Rodrigo Otávio, 6200, Manaus 69080-900, AM, Brazil; betcosta@gmail.com or betcosta@ufam.edu.br

* Correspondence: valdir.veiga@gmail.com

Citation: Souza, M.A.d.; Vilas-Boas, I.T.; Leite-da-Silva, J.M.; Abrahão, P.d.N.; Teixeira-Costa, B.E.;

Veiga-Junior, V.F. Polysaccharides in Agro-Industrial Biomass Residues.

Polysaccharides 2022, 3, 95-120.

https://doi.org/10.3390/

polysaccharides 3010005

Academic Editor: Cédric Delattre

Received: 26 November 2021

Accepted: 6 January 2022

Published: 9 January 2022

Publisher's Note: MDPI stays neutral with regard to jurisdictional claims in published maps and institutional affiliations.

Copyright: (C) 2022 by the authors. Licensee MDPI, Basel, Switzerland. This article is an open access article distributed under the terms and conditions of the Creative Commons Attribution (CC BY) license (https:// creativecommons.org/licenses/by/ $4.0 /)$.

\begin{abstract}
The large-scale industrial use of polysaccharides to obtain energy is one of the most discussed subjects in science. However, modern concepts of biorefinery have promoted the diversification of the use of these polymers in several bioproducts incorporating concepts of sustainability and the circular economy. This work summarizes the major sources of agro-industrial residues, physico-chemical properties, and recent application trends of cellulose, chitin, hyaluronic acid, inulin, and pectin. These macromolecules were selected due to their industrial importance and valuable functional and biological applications that have aroused market interests, such as for the production of medicines, cosmetics, and sustainable packaging. Estimations of global industrial residue production based on major crop data from the United States Department of Agriculture were performed for cellulose content from maize, rice, and wheat, showing that these residues may contain up to $18 \%$, $44 \%$, and $35 \%$ of cellulose and $45 \%, 22 \%$, and $22 \%$ of hemicellulose, respectively. The United States $(\sim 32 \%)$, China $(\sim 20 \%)$, and the European Union ( 18\%) are the main countries producing cellulose and hemicellulose-rich residues from maize, rice, and wheat crops, respectively. Pectin and inulin are commonly obtained from fruit $(\sim 30 \%)$ and vegetable $(\sim 28 \%)$ residues, while chitin and hyaluronic acid are primarily found in animal waste, e.g., seafood $(\sim 3 \%)$ and poultry $(\sim 4 \%)$.
\end{abstract}

Keywords: polysaccharides; agro-industrial residues; biomass; animal residues; forest residues; biopolymers; biodegradable materials; sustainable materials; macromolecules; carbohydrates

\section{Introduction}

According to the principles of biorefinery, biomass should have its use potentializednot generating waste but displaying a specific use for each obtained material. Initially, as in oil refineries, the main use of biomass has been related the direct transformation of agribusiness residues in biofuels and energy generation. This use has low added value and is only justified when processing large volumes and having available logistical facilities. On a small scale, the logistical costs of waste are high, mainly due to its high volume and low density, which makes its reuse processes difficult. Nowadays, novel processing steps and applications of residues have gained the attention of different markets, from small farmers to big manufacturers, due to the incorporation of circular economy concepts in bioeconomy models, chain valorization, and some of the sustainable development goals from United Nations (UN) [1]. The current scenario of imminent climate change makes the utilization of agro-industrial organic residues using sustainable methods industrially and economically relevant. Green technologies in chemical industries are among the most effective strategies for reducing greenhouse gas emissions, energy consumption, and solvent use [2,3]. It has been estimated that more than 1300 million tons of waste are produced annually by agro-industrial sectors, although other studies have reported diverse values [1,4]. Using the Food Loss Index, the FAO [1] estimated that in 2016, almost 14\% of all food produced 
globally was lost during the journey from farming to retail (without including it). In this same report, Central and Southern Asia stood out with the highest loss index of more than $20 \%$, followed by Northern America and Europe with more than $15 \%$. The commodities that displayed the highest losses from post-harvest to distribution in 2016 were roots, tubers, and oil-bearing crops at up to $25 \%$, followed by fruits and vegetables at more than $20 \%$, while cereals and pulses had the lowest values of less than $10 \%$ [1].

The lack of accurate information and harmonization of concepts regarding food waste in many countries has contributed to these differences $[1,5]$. There is no consensus on the definitions of food loss and waste because they often reflect problems reported by stakeholders or technical analysts, although many studies have used these terms [1-3,5]. It is known that food losses generally occur along food supply chain from harvesting/slaughtering to retail (but not including it), while food waste takes place at the retail and consumption points $[1,6]$. Waste comprises unused or unconsumed parts of vegetables, fruits, other plants or animals, and by-products from crops due to a lack of proper handling, processing conditions, inadequate sensorial/microbiological properties, and many other reasons for discarding [6].

The utilization of agro-industrial residues does not solely aim to increase economical profits; it is also aimed to help industrial companies create a more sustainable market. Current regulations are evolving to incorporate ESG (Environmental, Social, and Governance) concepts and requiring the traceability of the entire production chain until waste disposal. Companies looking to operate in the world's largest markets must pursue the UN's 17 Sustainable Development Goals (SDGs) [7]. SDG 12, Responsible Consumption and Production, calls for every company to reduce food loss and waste along production and supply chains (including post-harvesting losses) by 2030 [1]. Moreover, implementing practices to reduce food loss also affect other SDGs, such as Zero Hunger (SDG 2), Sustainable Water Management (SDG 6), Climate Change (SDG 13), Marine Resources (SDG 14), and Terrestrial Ecosystems, Forestry, Biodiversity (SDG 15) [1]. Moreover, receiving an ESG company certification is an important step towards demonstrating compliance with green and sustainable standards, as well as for differentiation from greenwashing companies.

The use of waste biomass to produce biopolymers and nutricosmetic or pharmacological materials is increasing, although still scarcely compared to its great potential, employment, and valorization. Organic waste biomass is a great source of natural polysaccharides such as cellulose, chitin, hyaluronic acid, inulin, and pectin. Biomass from the agricultural sectors is a relevant part of waste generation and commonly comprises leaves, roots, stalks, bark, bagasse, seeds, straw, wood, animal parts, crustacean shells, and others [3]. New biotechnologies based on green chemistry can be applied to improve the use and transformation of these residues into novel high value-added products, which can also minimize the production of non-renewable materials (50 billion tons of fossil fuels) and reduce dependence on non-sustainable resources [3,4,8]. These biopolymers from renewable resources have many useful technological and biological applications, such as in the preparation of nano or microcarriers, utilization as nutraceuticals ingredients, the development of novel food products, the design of biodegradable food packaging, and use as thickeners, gelling agents, colloidal stabilizers, texturizers, and emulsifiers [9-15].

This study addresses types and volumes of agro-industrial residues that are rich in five target biomolecules - cellulose, chitin, hyaluronic acid, inulin, and pectin (Figure 1) that are useful in diverse industrial and biotechnological (non-energy) applications. An evaluation of the global industrial residues based on the major crop production (from July 2020 to June 2021) of maize, rice, and wheat, as well as data from the United States Department of Agriculture (USDA), was performed to estimate cellulose content [16]. For the other polysaccharides, estimations were reviewed based on the literature.

The data survey related to the world's agricultural production and waste generation aimed to facilitate the assessment of potential extraction of cellulose due to its great availability because it is the most abundant polysaccharide in the world [17]. This review also highlights the physico-chemical properties and recent application trends of these polysac- 
charides. As their chemical structures are different, as shown in Figure 1, these differences result in a huge diversification of their functional properties and potential applications, as is presented in the following sections.

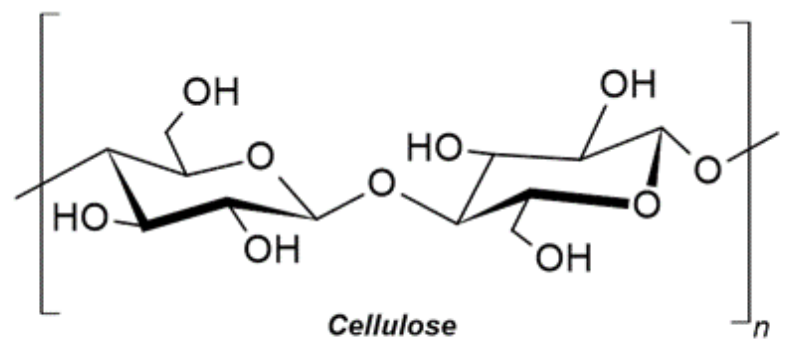

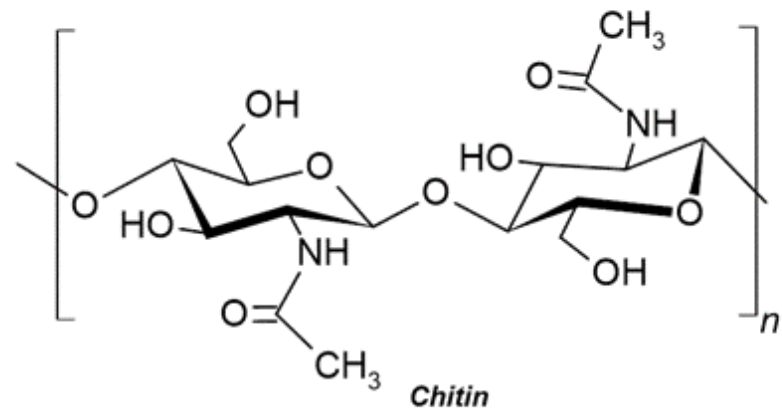

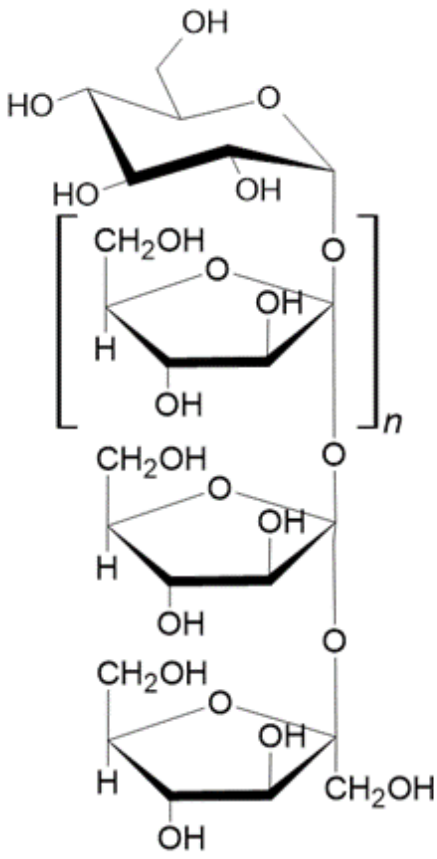

Inulin

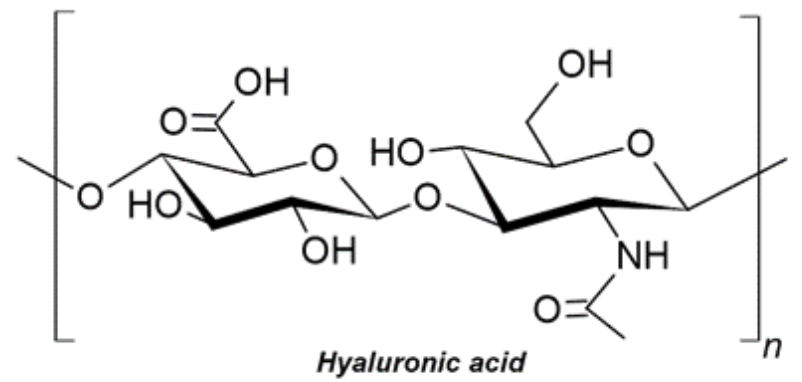

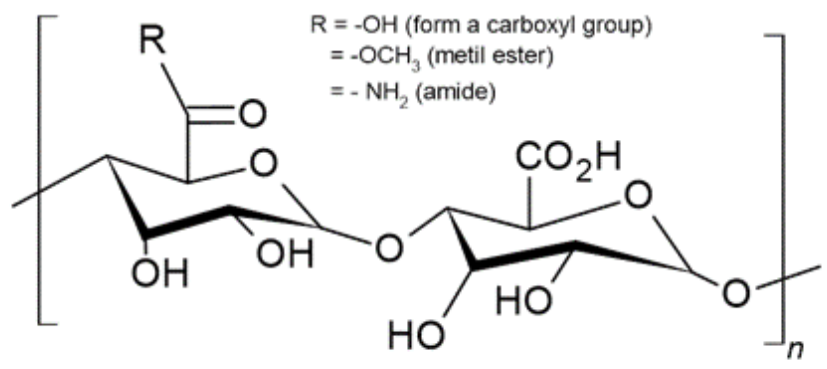

Pectin

Figure 1. Chemical structures of cellulose, chitin, hyaluronic acid, inulin, and pectin, which are important polysaccharides highlighted in the present study.

\section{A World of Waste: Industrial Biomass as a Source of Polysaccharides}

Polysaccharides are the most abundant biological materials on the planet. This natural abundance contributes to the discovery of their novel applications $[15,17]$. Their industrial use is still very modest considering their versatility and great potential, although it has recently seen significant increases. The use of these biopolymers grew about $17 \%$ in the years between 2017 and 2021, with the global market reaching 10 billion dollars in the first half of 2021 [16]. A report from Fact.MR estimated that the global polysaccharide and oligosaccharide market will reach a value over US $\$ 22$ billion with a compound annual growth rate (CAGR) of over 5\% during 2020-2030, especially because its use is related to "clean label" and sustainable developments in the food and beverages industries [18].

Other matrices, such as oilseed by-products, are also sources of polysaccharides, although in minor proportions depending on origin [19]. In the extraction of oleaginous products, such as palm oil and apple pomace, the pressing of extraction cakes (or pellets) can be an important environmental liability for the food and cosmetic industries due to the wide range of industrial potential $[20,21]$. For instance, a palm kernel cake, a by- 
product from palm kernel oil extraction, can contain up to $66 \%$ of carbohydrates comprising mannose, galactose, glucose, arabinose, xylose, and rhamnose, which have been found to be highly soluble (>95\%) [20].

The challenges for waste utilization include: (I) material availability, homogeneity and stability; (II) the selection of advantageous methods to separate, purify, and modify different chemical materials; (III) spoilage prevention before processing; (IV) the need to ensure the absence of toxic or pathogenic substances, such as microbial toxins, pesticides, heavy metals, and other contaminants, when used for food or feed; and (V) the development of sustainable processing steps to create high value-added products (Figure 2). Commonly, the extraction of valuable materials from biomass residues follows processes to first obtain food or medicinal-related substances, such as polyphenols and essential oils, and then polysaccharides, lignocelluloses, or waxes via advanced separation and depolymerization [3]. Many green techniques can be used for this, including the use of supercritical $\mathrm{CO}_{2}$, subcritical water, microwave (MW)-assisted extraction, gas-expanded liquids, and deep eutectic solvents or ionic liquids [3,4,9]. Agro-industrial activity can present greater social, economic, and environmental benefits if it manages to take advantage of all its biomass resources by implementing ESG concepts and attending to UN's 17 SDG.

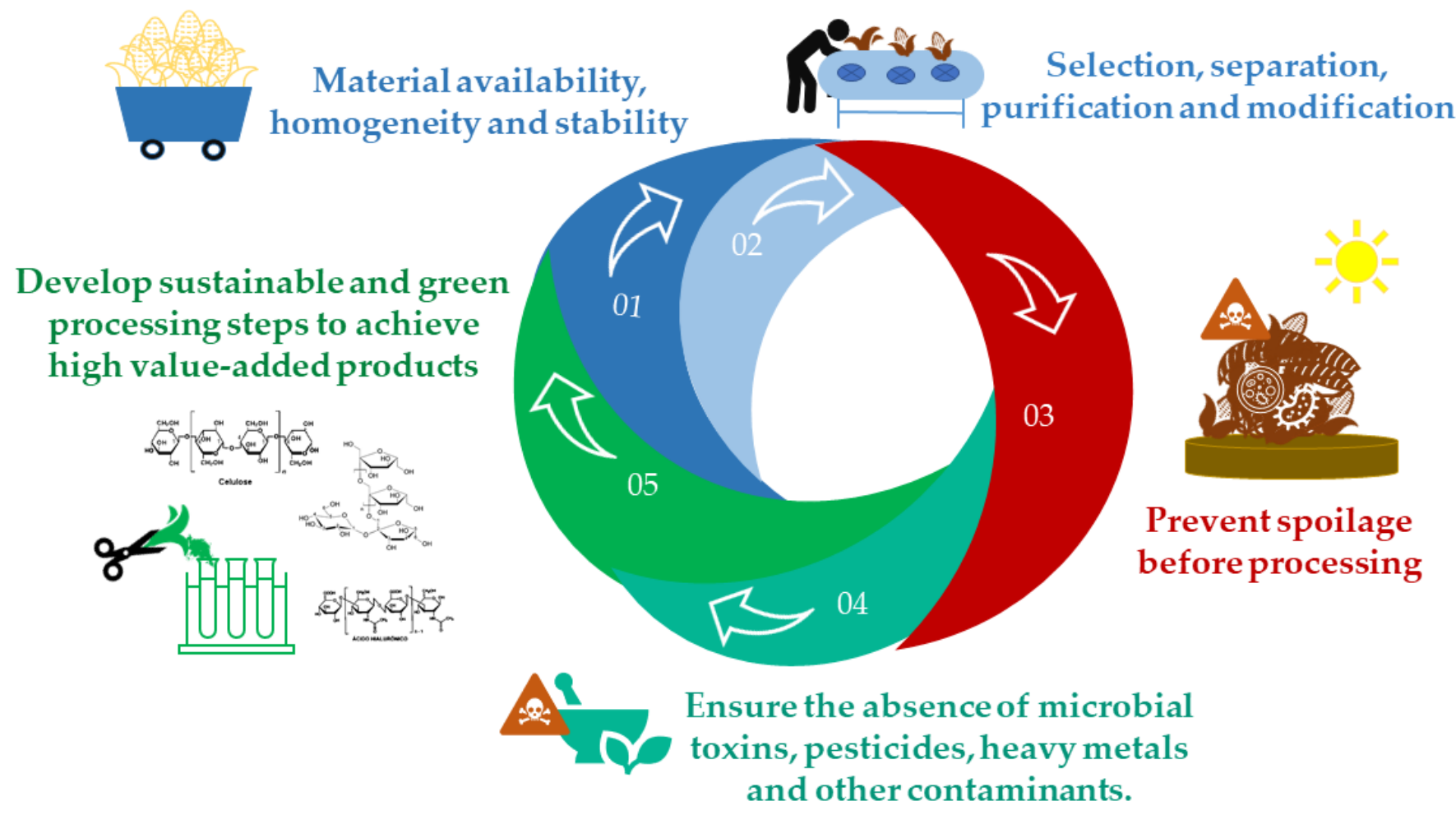

Figure 2. Summary of some challenges to be overcome for the utilization of residues.

\subsection{Cellulose}

Cellulose is a biodegradable and low-cost biopolymer obtained from renewable resources, e.g., wood and plants cell walls, some bacteria, algae, and (unusually) tunicates (the only known cellulose-containing animals) [17]. Its industrial global production is around $1.5 \times 10^{12}$ tons per year [22]. This production is predominantly the result of the cotton and wood industries, which use about $98 \%$ and $90 \%$ of pulp, respectively $[22,23]$. Cellulose is the most abundant polymer found in nature, and it is composed of glucose monomers linked in the $\beta(1-4)$ position $[17,22,23]$. Cellulose has a high molecular weight and a high propensity to form crystalline fibers. Four polymorphic types have been found and are classified as I, II, III, and IV according to the conformation of the carbon skeleton and the hydrogen bonds [23]. Cellulose can be found from five main sources: wood, plants 
and their residues, algae, animals, and bacteria [17]. These sources can be classified as: (I) conventional or primary ones, which are usually applied in the manufacturing of textile fibers, paper and wood for civil construction, and the obtainment of ethanol; (II) secondary ones, which are from unprocessed residues and directly obtained from the food industry or are agricultural and forestry residues, such as bark and leaves; (III) tertiary sources, which comprises processed residues from the use, transformation, and conversion of cellulosic biomass, e.g., bagasse and food residues; and (IV) quaternary sources belonging to a small group that includes marine animals, algae, fungi, and bacteria $[17,23]$. The first three levels of cellulose sources have common origin, mainly from plants. Table 1 shows the percentages of cellulose in some common types of agricultural residues, i.e., type III cellulose.

Table 1. Percentages of cellulose composition in plant residues.

\begin{tabular}{cccc}
\hline Waste & Vegetal Source & Cellulose (\%) & Reference \\
\hline Pseudo stem & Banana & 42.4 & {$[24]$} \\
\hline Stalk & Garlic & 41.0 & {$[25]$} \\
\hline Cob & Maize & 51.0 & {$[26]$} \\
\hline \multirow{2}{*}{ Bagasse } & Grape & 19.3 & {$[27]$} \\
\cline { 2 - 4 } & Carrots & 10.0 & {$[28]$} \\
\cline { 2 - 4 } & Tomato & 9.0 & {$[29]$} \\
\cline { 2 - 4 } & Manioc & 18.0 & {$[30]$} \\
\cline { 2 - 4 } & Garlic & 41.7 & {$[31]$} \\
\hline \multirow{2}{*}{ Husk } & Onion & 41.1 & {$[32]$} \\
& Oat & 38.7 & {$[33]$} \\
\cline { 2 - 4 } & Soybean & 45.0 & {$[34]$} \\
\hline
\end{tabular}

Many plant residues are promising for the isolation of cellulose molecules due to their chemical composition. However, as shown in Table 1, not all agricultural residues are cellulose-rich resources, making its extraction nonviable in some cases such as bagasse. In contrast, pseudo-stems, stalks, maize cobs, and barks that present more than $40 \%$ of cellulose are viable sources. Likewise, several aspects of the storage, moisture, presence of contaminants, volume, distance from industrial processing plants, other viable uses (such as fertilizer or to produce compost), local resources, and logistic facilities, among others, can act as enhancements or deterrents to the proper extraction of cellulose for use by biotechnology technologies.

Based on data of cereal production (from July 2020 to June 2021) collected from the United States Department of Agriculture (USDA) [16] in November 2021, the residual factor $(\%)$, residual mass (tons), residual polysaccharides (\%), and number of polysacchariderich residues ( $t$ ) for maize, rice, and wheat were estimated and are presented in Table 2. The determination of the residual factor was calculated according to the methodology of the Brazilian Association of Biomass Industries [35]. These crops are interesting in the context of cellulose recovery due to their great availability, since they are among the major produced cereals and account for more than $90 \%$ of all cereal consumption worldwide [36]. Together, these crops comprise about 1200 million tons of discarded waste per year. However, we found that wheat showed the highest residual factor, followed by maize and rice, as can be seen in Table 2. Accordingly, the residues from these cereals can be considered a cellulosic-rich biomass. Rice displayed the lowest residual factor, though it could contain the highest proportion of cellulose of up to $44 \%$, while maize displayed the lowest content of cellulose of around $18 \%$. The differences between these cereals are 
linked to their intrinsic characteristics, such as those inherent to the species, as well as to the applied processing technique, such as dry or wet milling. Dry milling is generally applied to wheat, whereas wet milling is common for maize, and pearling is applicable to rice and barley [37]. Maize residues comprise biomasses from cob, husk, germ, bran, and gluten [37]. This crop presented the highest production and residue volumes of almost 1200 and 700 million metric tons per year, respectively, compared to the other cereals (Table 2) [16]. This highlights its great viability for cellulose and hemicellulose extractions.

Table 2. Biomass, estimative residual mass, percentage factor, and polysaccharides content of three major cereal crops in 2021.

\begin{tabular}{cccccc}
\hline Crop & Production (Tons) & $\begin{array}{c}\text { Residual Mass } \\
\text { (Tons) }\end{array}$ & $\begin{array}{c}\text { Polysaccharide-Rich } \\
\text { Residues (Tons) }\end{array}$ & $\begin{array}{c}\text { Residual Factor } \\
\text { (\%) }\end{array}$ & $\begin{array}{c}\text { Residual } \\
\text { Polysaccharides (\%) }\end{array}$ \\
\hline Maize & $1,197,767$ & $694,704.86$ & $435,996.77$ & 58 & $62.7(18 \mathrm{CS}+44.7 \mathrm{HC})$ \\
Rice & 507,945 & 101,589 & $66,743.97$ & 20 & $65.7(43.5 \mathrm{CS}+22.0 \mathrm{HC})$ \\
Wheat & 780,279 & $468,167.40$ & $266,855.42$ & 60 & $57.0(35.4 \mathrm{CS}+21.6 \mathrm{HC})$ \\
Total & $2,485,991$ & $1,264,461.26$ & $769,596.16$ & & \\
\hline
\end{tabular}

CS: cellulose; HC: hemicellulose.

Cereal production data from July 2020 to June 2021 regarding maize, rice, and wheat were collected from the United States Department of Agriculture [16], obtained in November 2021, listing the major producers of each cereal crop to this harvest. In next figures, we present the total production volume (in thousand metric tons, represented by the blue color bar), waste production (represented by the orange color bar) $\mathrm{m}$ and polysaccharide residues (represented by the gray color bar) of the major producing countries are graphically listed. The amount of polysaccharide residues was estimated based on a residual factor of $58 \%$, as previously presented in Table 2. The major global producers of maize in the year of 2020-2021 are presented in Figure 3.

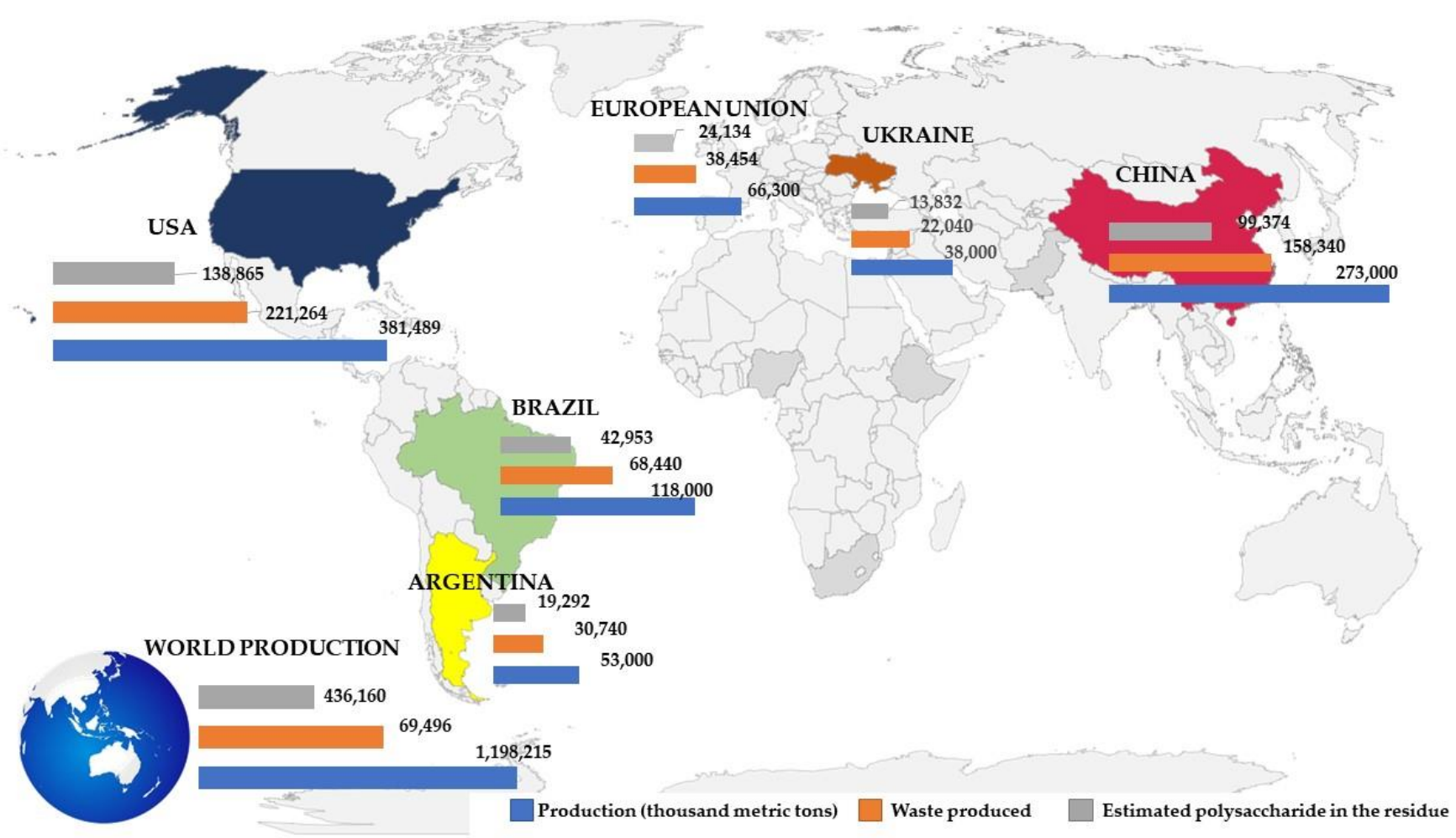

Figure 3. Main global producers of maize in the year of 2020-2021: total production (in thousand metric tons, blue bars), waste production (orange bars), and estimated polysaccharide residues (gray bars). 
In Figure 3, it is possible to observe that maize production was well-distributed in countries that have a temperate and sub-tropical climates. The total production was about 1.2 billion metric tons. In all these countries, the waste production plus the amount of polysaccharides residues reached almost $50 \%$ of the total maize production. The largest producer was the United States (USA) with more than 380 million metric tons of maize, followed by China (273 million metric tons) and Brazil (118 million metric tons). These three countries have been dominating maize production since 2012 [36]. As these are the major producers, it was also expected that they exhibited more waste production for this crop (Figure 3). The USA, China, and Brazil have increased their production of maize by more than $38 \%, 31 \%$, and $60 \%$, respectively, in the last 10 years [36]. Although these are the main producers of maize, the countries that presented the highest consumption of this cereal are low-income economies from Africa, Central America, and Southeast Asia, e.g., Lesotho, Malawi, Zambia, Mexico, and Timor [36]. China has shifted from being the second largest exporter in some years to sporadically having higher importation quantities, thus causing some uncertainty in world market trade [36]. The main use of corn in the USA in 2013 was for ethanol production and animal feed, which together comprised up to $87 \%$ of the production volume, while the remaining was destinated to food, seed, and industrial applications [36].

Figure 4 illustrates the estimated world production of cellulosic waste from maize distributed in more than 16 countries. This estimation is expressed in produced tons. The major producers were found to be the United States (USA) with $\sim 32 \%$ of maize production, followed by China ( 23\%) and Brazil ( $10 \%)$. USA and China dominated more than 50\% of this production. Thus, the USA, China, and Brazil were found to be responsible for the generation of more than 448,000 tons of residues from maize production. The main destiny of this residue is for use in the production of ethanol and animal feed [36]. For all cereals, the outliers (such as husks), contain not only cellulose but also other macromolecules (such as lignin, complex xylans with different ratios of arabinose to xylose, and other important micronutrients, e.g., proteins, polyphenols, and minerals), which are lost when using it for fuel production $[38,39]$. Thus, the utilization of this biomass in the production of biological polysaccharides and functional biomolecules should be stimulated and pursued.
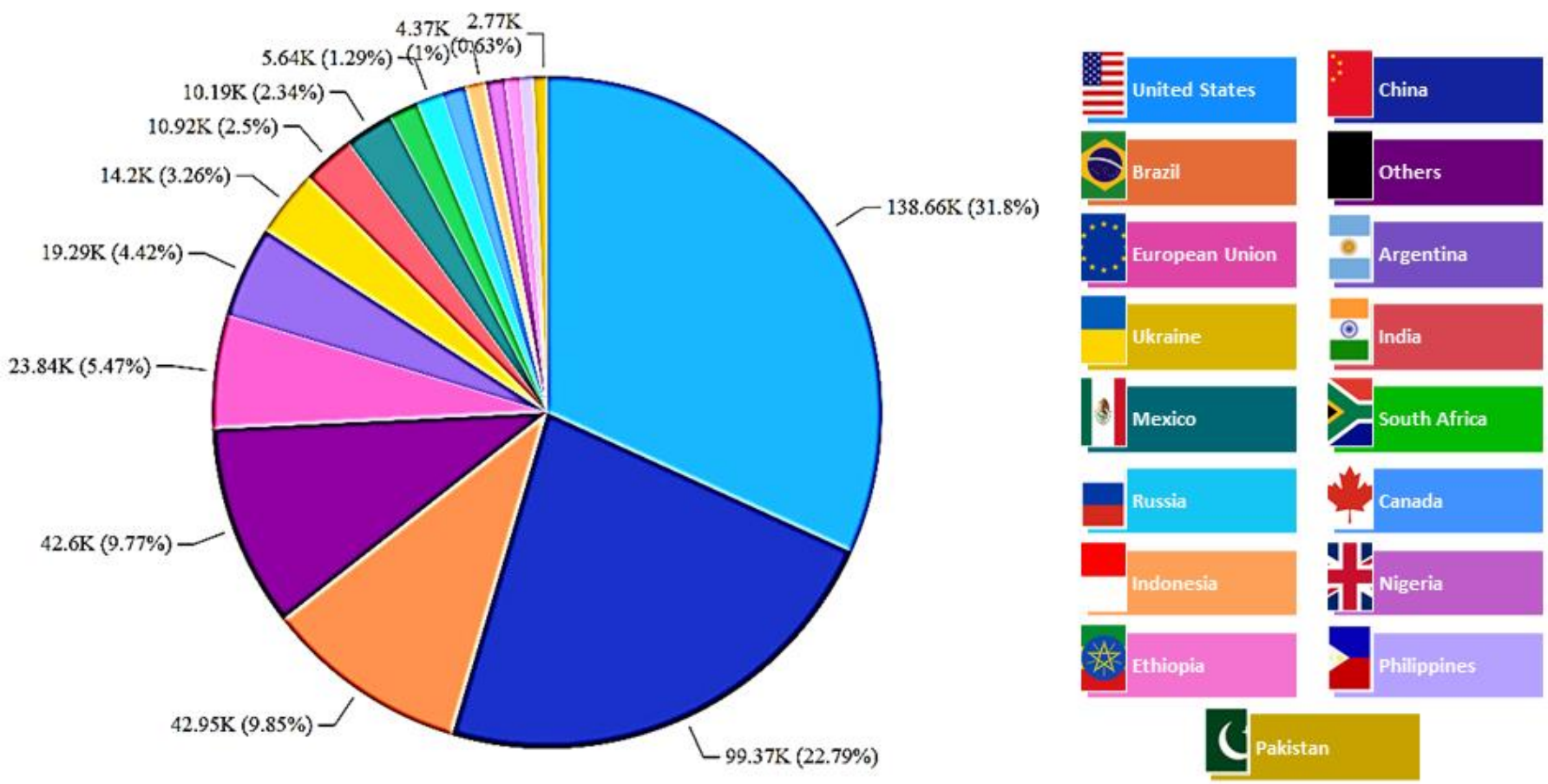

Figure 4. World distribution of cellulosic-waste production from maize (thousand metric tons). 
Figure 5 illustrates the main global producers of rice in the year of 2020-2021. Rice was the second most cultivated grain with high consumption by different populations across the world that total about half a billion metric tons. Rice production was dominated by countries with tropical climates, mainly in Asia. The world largest producer of rice was China, reaching almost 150 million metric tons in 2020, followed by India (125 million metric tons), Indonesia (35.4 million metric tons), Vietnam (27.1 million metric tons), and Thailand (19.5 million metric tons) [16].

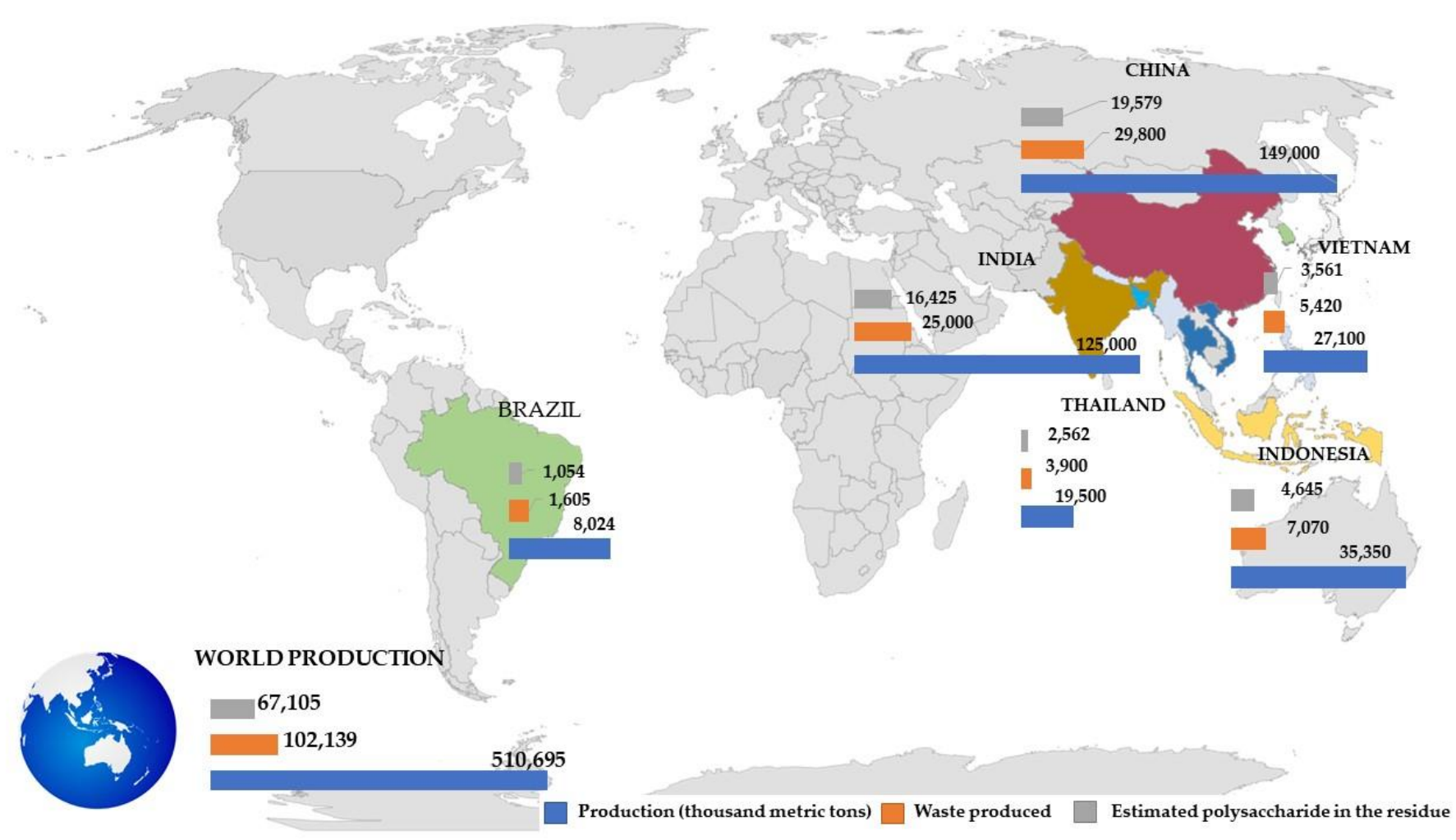

Figure 5. Main global producers of rice in the year of 2020-2021: total production (in thousand metric tons, blue bars), waste production (orange bars), and estimated polysaccharide residues (gray bars).

These countries were also the main producers of rice in 2018/2019 according to the World Atlas, together reaching a producing volume of more than 651 million metric tons of rice [40]. In 2018/2019, China had a rice production around 148 million metric tons, mainly cultivated in provinces such as Jiangsu, Anhui, Hubei, and Sichuan by the Yangtze River [40]. In India, rice production in 2016 reached over 116 million metric tons, largely being produced by the West Bengal state [40]. Indonesia stood out as the third-largest world producer of rice, producing over 36.7 million metric tons in 2018/19 that was mainly cultivated on the islands of Java and Sumatra [40]. As rice production is spread across small villages/provinces, full access to generated residues can be difficulted due to logistical infrastructure. In this case, it is important to have governmental policies and legislations to support the utilization of these residues in other purposes besides energy applications.

As rice has an elevated production volume, it is also expected that its processing steps generate higher amounts of cellulosic-rich waste, as well as other nutrients. Rice husk (pericarp) comprises around $2 \%$ of the grain weight and can contain up to $43 \%$ of cellulose and $30 \%$ of hemicellulose, although this can differ among species [41,42]. Additionally, up to $74 \%$ of total dietary fiber, around $20 \%$ of minerals, up to $3 \%$ of proteins, and less than $1 \%$ of lipids, among other micronutrients, can be found in rice husks [41]. Fibers from rice straw have displayed high-quality and more suitable properties than other natural cellulose fibers extracted from agricultural byproducts, especially when considering composite and 
textile applications because of their mechanical and functional properties, e.g., crystalline proportion, strength, and elongation [42,43].

The estimated world production of cellulosic waste from rice is shown in Figure 6. For this crop, more than 15 waste-producing countries are listed. It can be noted that the major rice producers-China $(\sim 31 \%)$, India $(\sim 26 \%)$, and Indonesia $(\sim 7 \%)$-were responsible for almost two thirds of the total waste production from this cereal. Following these three main producers were other countries from Southeast Asia, such as Vietnam ( 6\%), Thailand $(\sim 4 \%)$, Birmania (Myanmar) $(\sim 3 \%)$, and the Philippines $(\sim 3 \%)$-small countries that together represent about $15 \%$ of all global rice-waste production.
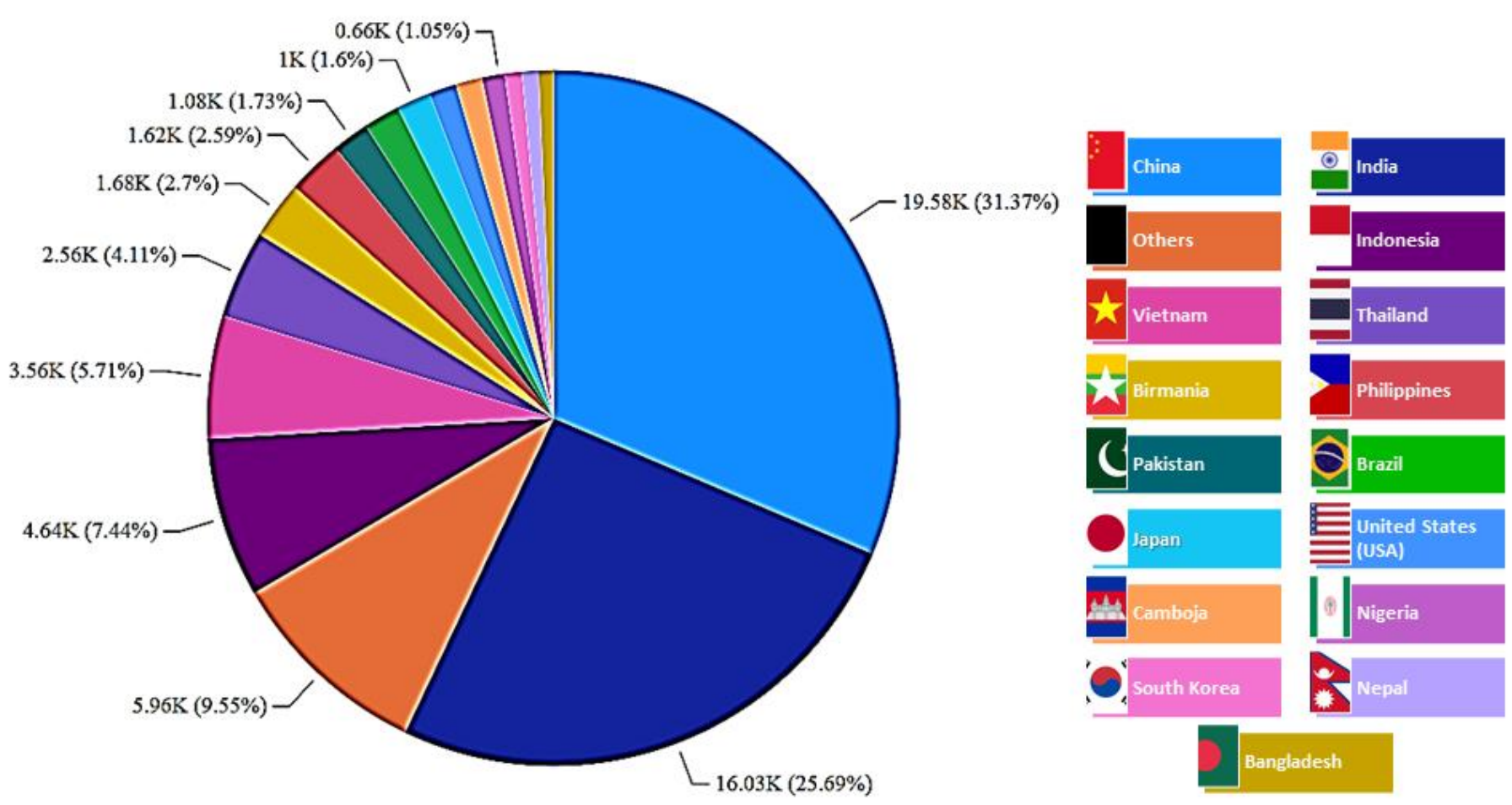

Figure 6. World distribution of cellulosic waste production from rice (thousand metric tons).

Wheat is the third largest agro-industrial crop, and its processing also generates high amounts of cellulose-rich residues. The major global producers of wheat in the year of 2020-2021 are presented in Figure 7. The total wheat production reached over 775 million metric tons in this period, and it was mainly dominated by the European Union, with a volume close to 139 million tons [16]. In 2012, the worldwide production of wheat was around 670 million metric tons [44]. In 2020-2021, China was the second largest producer of wheat with more than 136 million tons, followed by India with almost 110 million tons and Russia with more than 72 million tons. The sustainable use of fertilization, irrigation, and underexploited lands, such as in Russia, Eastern Europe, and North America, could increase the world wheat production but approximately $50 \%$, though it is expected that climate change, especially the rising temperatures, will affect wheat production [45].

The main use of wheat is for human food consumption, where it is milled into flour [46]. Around $80 \%$ of the grain is milled for flour production, and the remaining proportion comprises side-streams that are mainly composed of wheat germ and bran, which can account up to $25 \%$ of grain weight [46]. It has been reported that over 150 million tons of wheat bran are produced every year, and these are mostly used for livestock feeding [46].

Histologically, the structure of wheat outer layers is formed by a thick cellulosic cell wall containing cuticle substances and complex xylans with high arabinose to xylose ratios and substituted ferulic acid dehydromers as chain crosslinkers [46]. Nutritionally, wheat bran mostly contains carbohydrates (which comprise up to $56 \%$ ), followed by $18 \%$ of 
proteins, and 3.5\% of lipids [46]. Chemically, complex structures of either C6-sugars such as cellulose or $\mathrm{C} 5$ sugars such as xylans, phenolic compounds, and lignin can be found in wheat bran [46]. These properties of wheat by-products enhance their potential applications in diverse chemical and food industries.

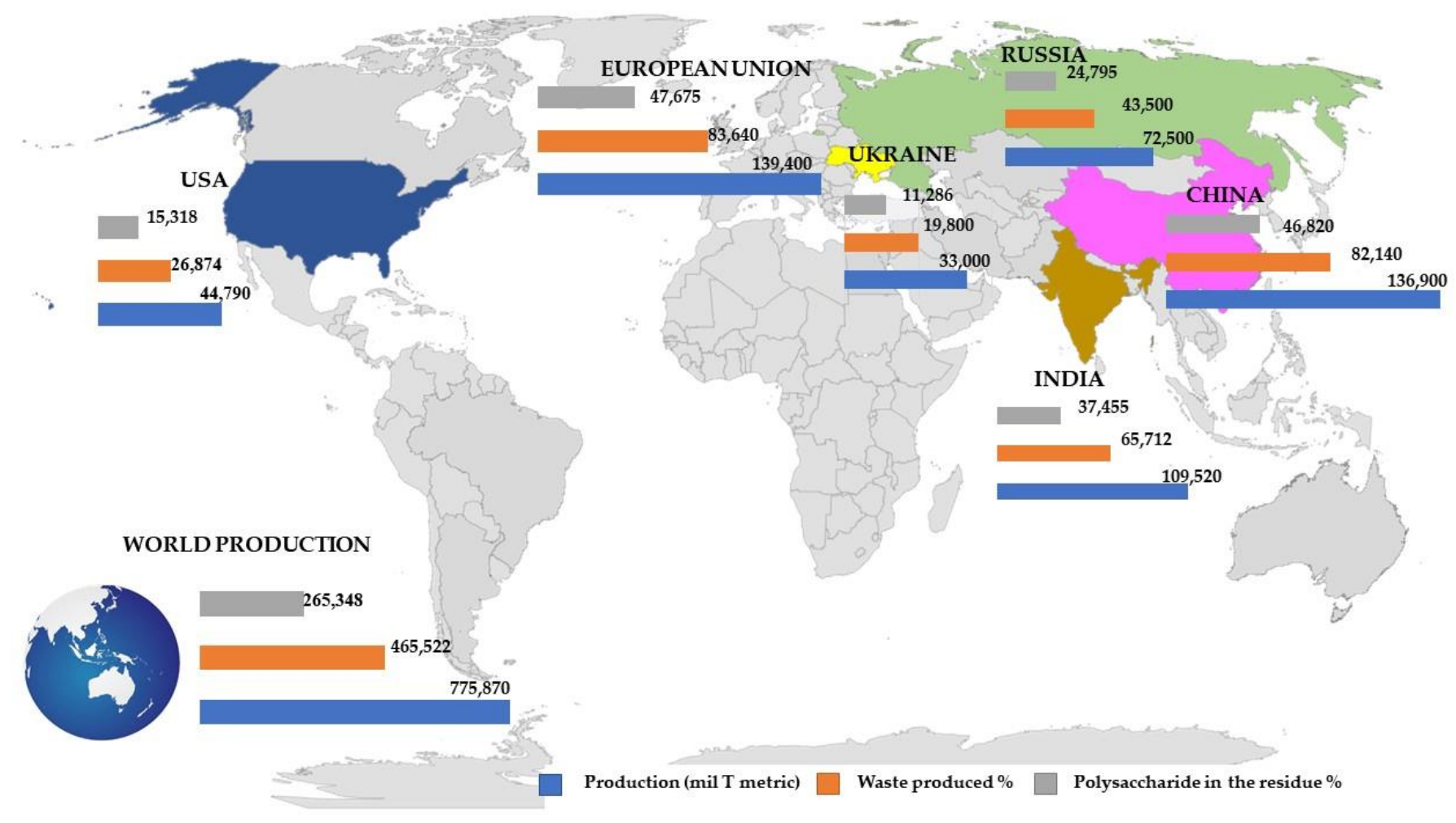

Figure 7. Main global producers of wheat in the year of 2020-2021: total production (in million metric tons, blue bars), waste production (orange bars), and estimated polysaccharide residues (gray bars).

Figure 8 shows the world production of cellulosic waste from wheat; more than 15 countries are listed, and their waste production is estimated. The major waste producers from wheat processing were found to be the European Union $(\sim 18 \%)$, China $(\sim 17.5 \%)$, India $(\sim 14 \%)$, and Russia $(\sim 9 \%)$. These four countries dominated more than $50 \%$ of all wheat-waste production, followed by the USA, Ukraine, Australia, and others.

Natural cellulose can be found in four basic forms, fiber, filaments, crystals, and micro/nanofibrils, all of which influence its application [17]. The diversified use of cellulose depends not only on its origin source but also on its morphological shape, crystallinity, and physico-chemical properties [17]. Macromolecules extracted from agro-industrial residue have potential for multiple uses beyond their employment in the paper and energy industries. These materials can be used in the manufacturing of disposable diapers, textile materials, absorbents, tablet fillings, emulsifiers, thickeners, and stabilizers, as well as in diverse chemical/pharmaceutical applications, due to their rich content of versatile macromolecules and phenolic substances $[12,15,17]$. In the food industry, an example of their employment is the production of novel cellulosic synthetic viscera to make sausages without the use of animal parts [47]. Another example is the manufacture of a thin film with antioxidant and antimicrobial properties based on chive root extracts and carboxymethyl cellulose to food packaging [48]. In pharmaceutical industries, cellulose is commonly used at the nanoscale to coat the tablets and capsules of drugs [49]. Cellulose nanoparticles also serve as carriers for the controlled release of certain medicines due to their resistance to human enzymatic degradation [50]. Another recent application in biomedical field is the use of cellulose for the manufacturing of intelligent wound-dressings and artificial skins [51]. 

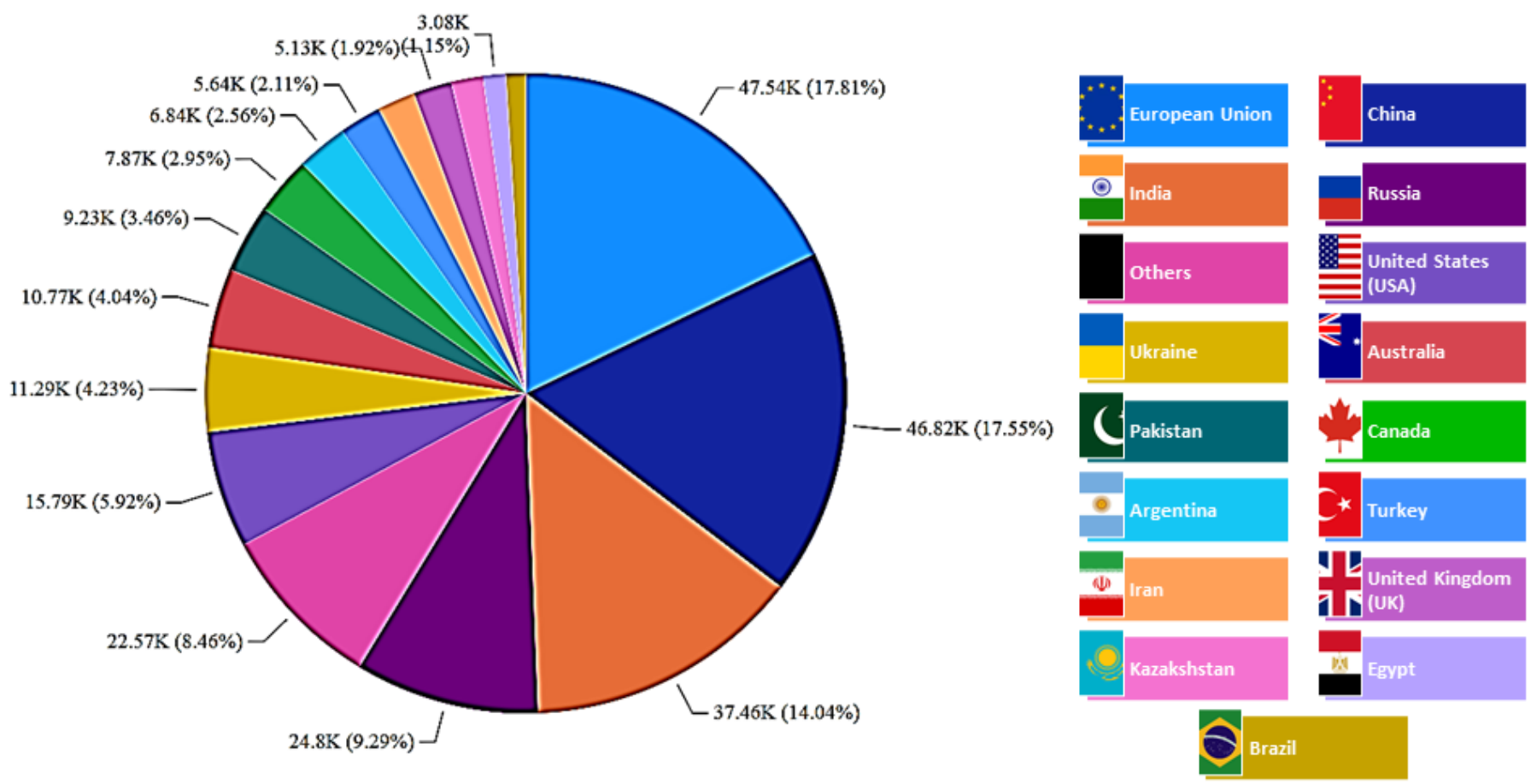

Figure 8. World distribution of cellulosic waste production from wheat (thousand metric tons).

Cellulose in Waste from Exported Crops

Because maize, rice, and wheat are the three most important crops in the world for human and animal feed and they extremely rich in cellulose content, their export data allowed us to create an overview of countries that export grains but keep their residues. Figures 9-11 show estimations of cellulose contents correlated to the amount of exported maize, rice, and wheat, respectively, per ton in the 2020-2021 harvesting season.

The estimations of cellulose content in retained residues from cereal export data of the USDA [16] during the harvesting period of July 2020 to June 2021 showed different patterns. Regarding maize, the countries that retained the greatest content of cellulosic-rich residues were the USA, Argentina, Brazil, and Ukraine (Figure 9), which differed from the largest waste producers in maize processing (Figure 4). In terms of exportation in the 2020-2021 harvest, the United States was the largest maize exporter in the world, thus displaying the greatest cellulose content in retained residues. The USA maize exports grew up $20 \%$ from 2019 to 2020 , mainly due to a strong demand from China, which was the third largest USA maize export destination after Mexico and Japan in 2020 [52]. Just to China, the USA exported a total of 1.2 billion dollars in maize [52]. Together, China, Mexico, and Japan accounted for $62 \%$ of total USA maize exports [52]. Argentina, Brazil, Ukraine, and Russia also stood out as exporters of this same crop, with numbers close to those of the USA. Recently, Argentina established a new limit on maize exportation for 2020/2141.6 million tons - to ensure sufficient supplies for domestic use and to reduce inflationary pressures [53]. Brazil maize exportation has significantly increased over the last decade, from around 52 million tons to more than 98 million tons in 2017/18, especially expanding in Asian and African markets, such as those of Islamic Republic of Iran, Japan, the Republic of Korea, Vietnam, Malaysia, Egypt, Morocco, and Algeria [54]. Other countries with smaller cultivation landsites, such as European countries, were demonstrated to be minor maize-exporting countries. 


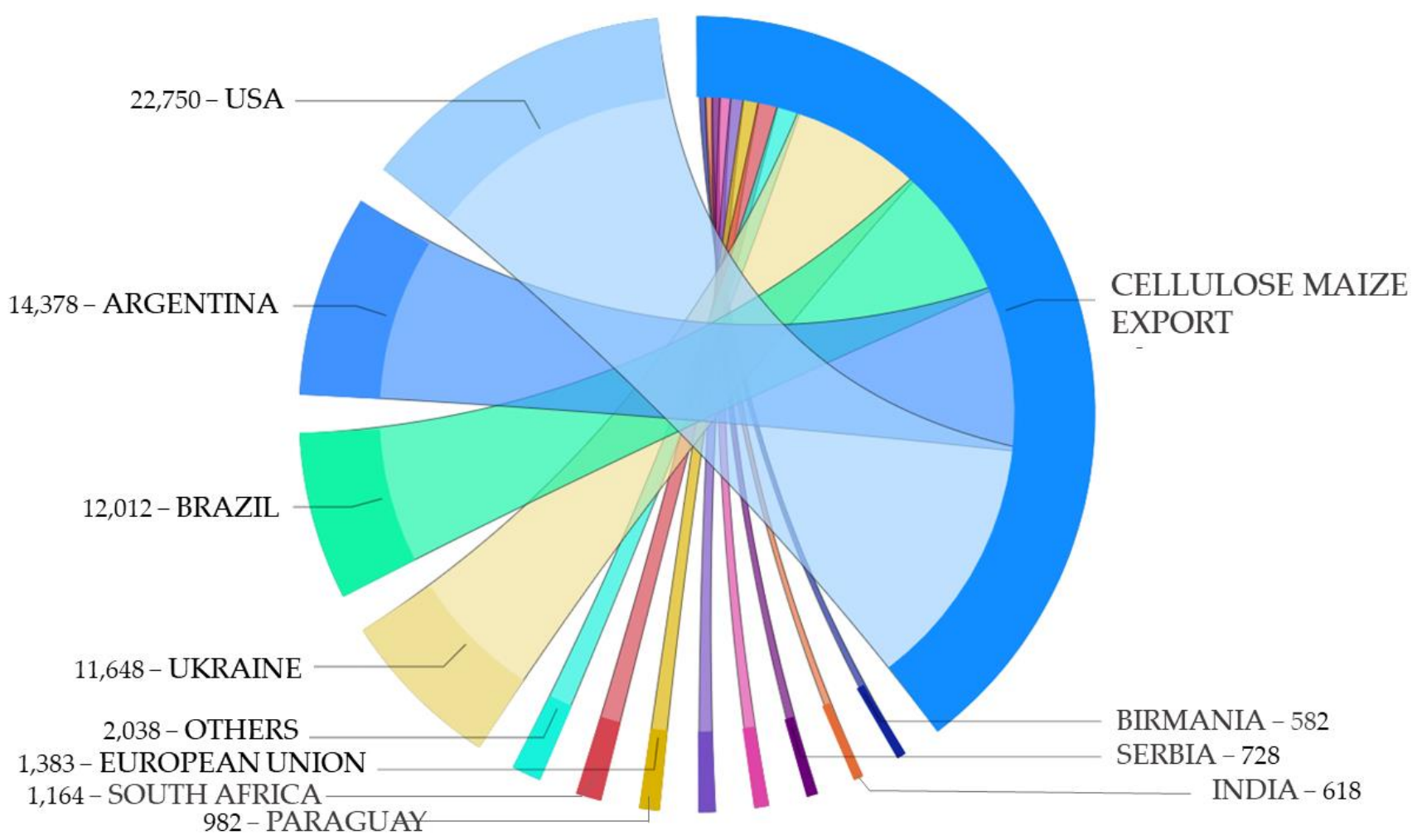

Figure 9. Estimation of cellulose content in residues retained from exported maize in 2020 (metric tons).

Figure 10 presents an estimation of cellulose content correlated to the amount of exported rice per ton in the 2020/21 harvesting season.

Although China, India, and Indonesia were the highest rice waste producers in 2020 (Figure 6), they were not all the biggest rice exporters, as shown in Figure 10. The main rice exporter was India, followed by Thailand, Vietnam, and Pakistan [16]. According to Reuters [55], India is intending to expand its rice exports to over 22 million tons in 2021 and becoming the leading rice exporter with $45 \%$ of the global market. India's exports of non-basmati rice doubled from 2020 to 2021 from 9.7 to 18 million tons, respectively, while the basmati rice exports reached around 4 million tons [55]. Basmati rice is an aromatic and fine-quality grain that is commonly cultivated in the Himalayan mountain regions of India and Pakistan, with which its name is traditionally associated [56,57]. Vietnam, the third largest rice exporter in the world, presented a decrease in grain exports in 2020 of around $3.5 \%$ to 6.15 million tons, mainly because due to disruptions of supply chains caused by the COVID-19 pandemic [58]. Thailand and Vietnam maintained their second and third positions, respectively, in the global rice exportation race because Thailand recently witnessed staggering growth due to rigorous regional lockdown from August to September 2021 [59].

Figure 11 presents an estimation of cellulose content correlated to the amount of exported wheat per ton in the 2020/21 harvesting season.

The European Union, Russia, and the USA were the major wheat exporters in 2020/21, as can be seen in Figure 10 [16]. However, Russia and the USA were not among the major wheat producers, which were China and India (Figure 7). The three major exporters were responsible for retaining up to 32.3 million metric tons of cellulose-rich residues from exported wheat grains (Figure 11). The European Union was the largest wheat exporter, with up to 16.4 million metric tons from July 2020 to February 2021 according to S\&P Global Platts [60]. The USA;s wheat exports reached up to $\$ 6.3$ billion in 2020, with a low growth (1\%) from 2019 due to a higher demand from its largest buyer, China, while 
Mexico, the Philippines, Japan, and South Korea accounted for $41 \%$ of the USA's total wheat exports [61].

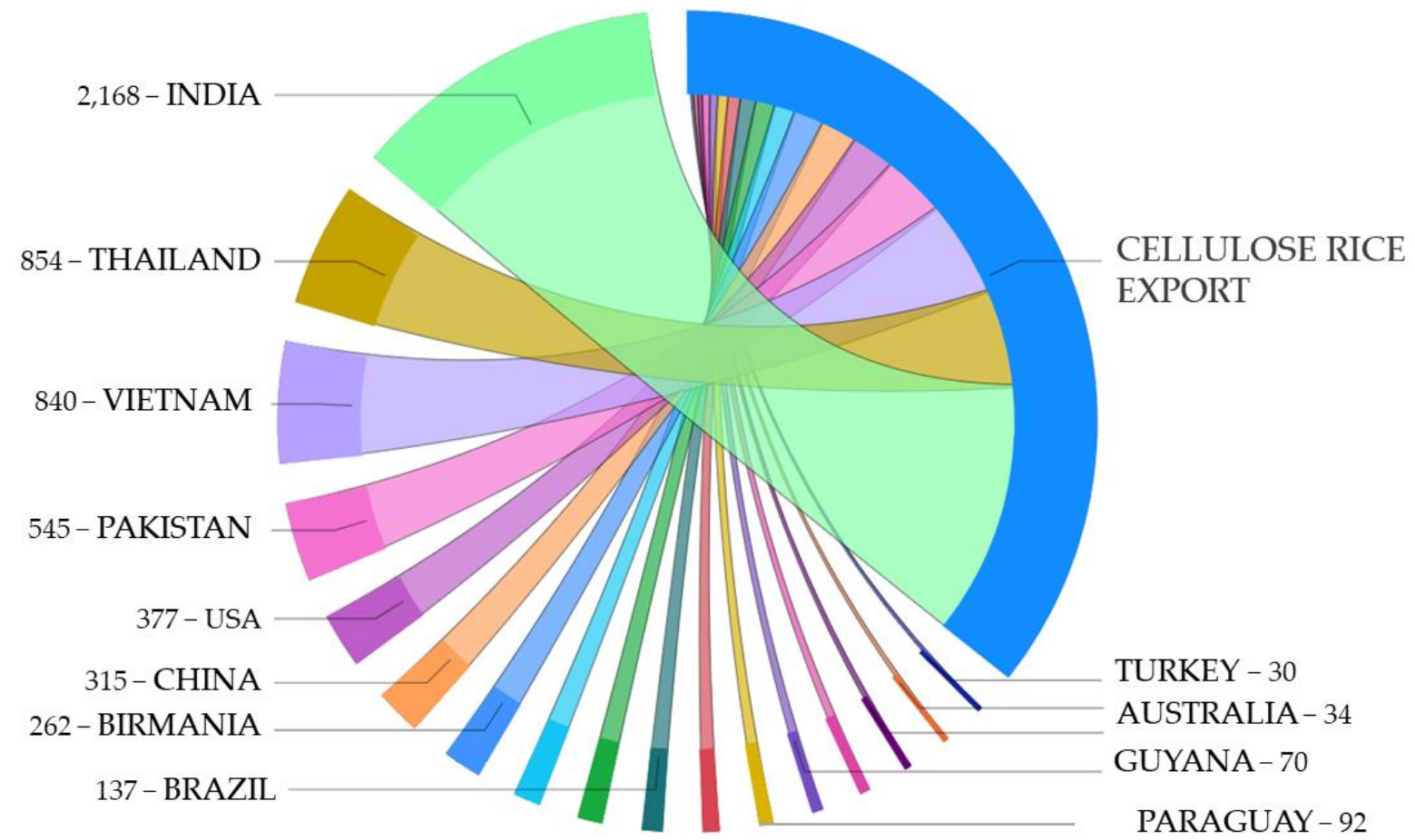

Figure 10. Estimation of cellulose content in residues retained from exported rice in 2020 (metric tons).

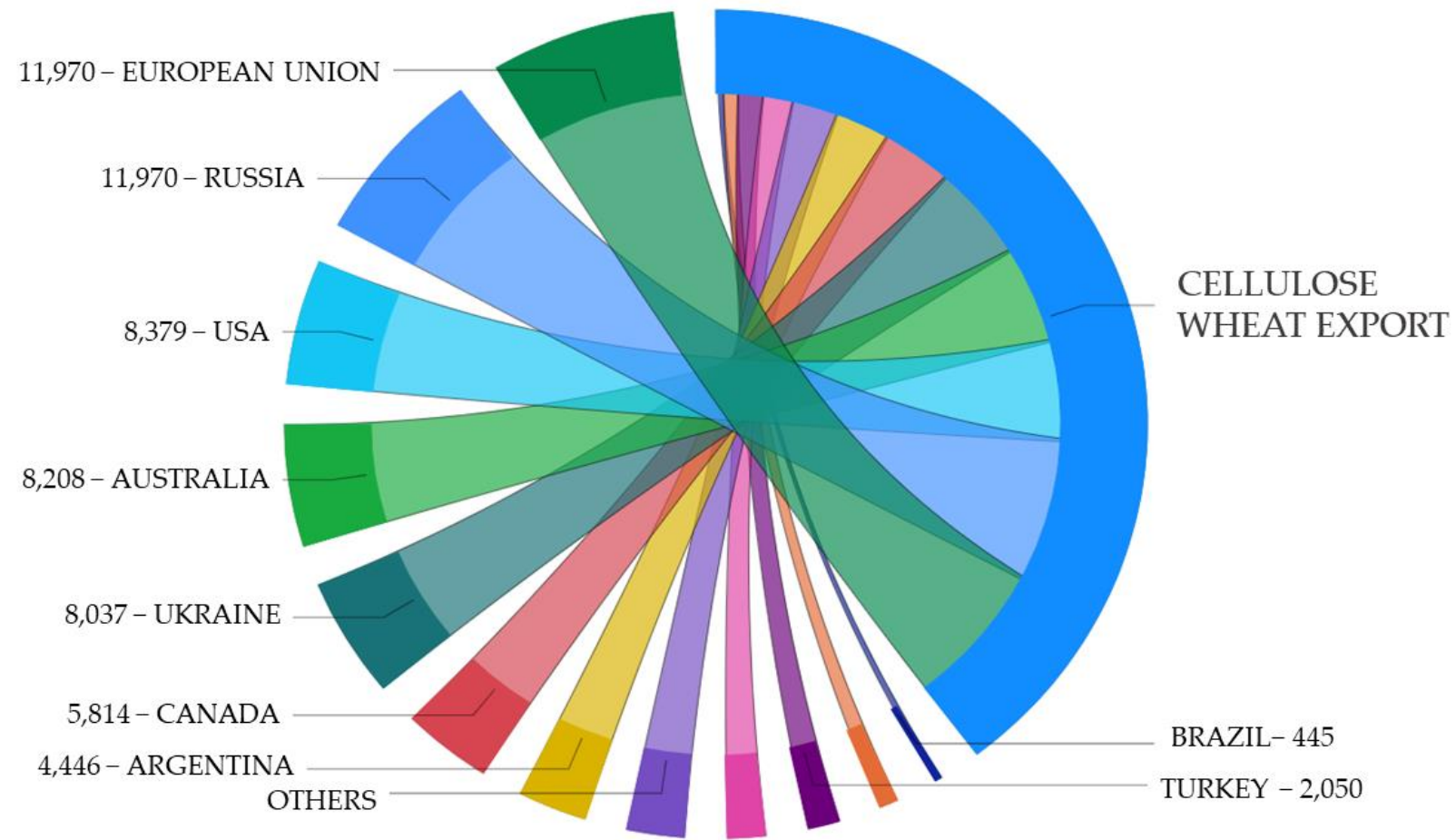

Figure 11. Estimation of cellulose content in residues retained from exported wheat in 2020 (metric tons).

Moreover, the United States led with maize exports, India led with rice exports, and the European Union led with wheat exports. These patterns show that these countries may have disposed of significant volumes of valuable polysaccharides as waste, which could 
be used for different purposes in many industrial sectors and, consequently, increase its economic strength.

\subsection{Inulin}

Inulin is a natural polysaccharide found in more than 30,000 species of plants, with cereals, tubers, and roots being its main commercial sources [62]. The most common residual sources of this polysaccharide are chicory, asparagus, garlic, banana, onion, rye, barley, and wheat, although it can be found in other unconventional sources, e.g., açaí seeds [62-65]. Inulin can also be enzymatically produced and obtained from genetically modified potatoes [66]. On the other hand, food residues may have slightly higher contents of inulin, such as onion with $\sim 18 \%$ and garlic with $~ 28 \%$ of dry mass [67].

Inulin is a distinctive oligo- or polysaccharide because any sugar ring is part of its backbone (Figure 1), which is characterized by linear fructose chains, joined by glycosidic bonds formed by $2-100$ monomeric units [62-64]. Its chains are mainly formed by furanose groups, giving more flexibility than pyranose rings [64]. Due to its long polymeric chain and glycosidic bonds in $\beta-(2-1)$ position, inulin is insoluble at body temperatures and resistant to salivary amylase and intestinal enzymes, thus showing potential for use in the food and pharmaceutical industries $[64,66]$. Inulin can contain up to 10 fructose units, so it is classified as a fructo-oligosaccharide (FOS) and is considered a prebiotic [62,65]. As it serves as carbohydrate storage in many plants, inulin can also be found in the processing residues of fruits and vegetables such as husks, seeds, stems, and bagasse $[68,69]$. These by-products are generally side streams from processing steps such as pulping, cleaning, sieving, and food bleaching, which are necessary for food processing and preservation [6].

Industrially, inulin is processed from several raw materials, although its major sources are chicory roots (Cichorium intybus) and Jerusalem artichoke (Helianthus tuberosus) [63]. Nevertheless, there have been several laboratorial studies scaling up inulin extraction from other raw materials, such as burdock (Arctium lappa), dahlia (Dahlia spp.), garlic (Allium sativum), onion (Allium cepa), jicama and agave tequilana (Agave tequilana Weber var. Azul). Jicama, also known as "yacon", is composed of approximately $60-70 \%$ of FOS (in dry basis), therefore being a very attractive source of this oligosaccharide [70]. Moreover, the most inulin-rich plants are in both the monocotyledonous and dicotyledonous families. Inulin can also be found in the bulbs, tubers, and tuberous roots of many plants such as Dahlia pinnata (Dahlia), Taraxacum officinale (Dandelion), Asparagus officinalis (Shatwaar), and Asparagus racemosus (Shatavari) [71,72].

Inulin extraction can be carried out with different methods mainly based on water, such as infusion in hot water (up to $90^{\circ} \mathrm{C}$ ), deep freezing followed by precipitation after defrosting, concentration and crystallization steps, and freeze-drying followed by optimized hot water extraction [63,73]. It is important to highlight that the use high temperatures in the inulin extraction process by diffusion in water is crucial, since the solubility of inulin increases with temperature [62,73]. Raw materials such as tubers or roots should be washed, sliced, or milled prior to inulin extraction, followed by filtration and recovery with evaporation or precipitation methods $[62,73]$. The purification process can involve other steps, e.g., liming, carbonation, filtration, demineralization, and decolorization [62]. Although many studies have investigated alternative sources of inulin extraction, its main source continues to be chicory root, a vegetable residue from the lettuce family known for its bitter taste $[62,70]$. Inulin extraction from chicory roots is commercially viable due to the high yield of the generated residues from the agricultural cultivation of chicory. When processed as powdered syrup, with concentrations ranging from $90 \%$ to $98 \%$, the market prices for it can range from $\$ 1.00$ to $\$ 100.00$ per pound depending on the concentration required by the consumer [74]. The extraction market of this polysaccharide is predominantly constituted by Chinese companies [74].

Inulin is a mixture of linear fructose oligomers and polymers with a variable degree of polymerization (DP) ranging from 2 to 65 units, with an average degree of polymerization $(\mathrm{DP}$ av $)=12$ [75]. Additionally, inulin has been given the status of Generally Recognized 
as Safe (GRAS) by the Food and Drug Administration (FDA) for its various properties, including biodegradability, renewability, and non-toxicity $[66,76]$. Structurally, inulin $\left(\alpha-D_{-}\right.$ glucopyranosyl- $\beta$ - $D$-fructofuranoside- $(n-1)$ - $D$-fructofuranoside) is composed of $\beta$ - $D$-linked fructosyl oligomer $(2 \rightarrow 1)$ with a glucose at the reducing end, and it is the second most abundant polysaccharide $[62,66,76]$. As a natural polysaccharide, inulin belongs to a class of non-digestible dietary fibers known as fructans, which exhibit functional properties in human intestinal microbiota by stimulating the growth of probiotics in the gut [62,64]. It can also be used in lipid metabolism and mineral ion absorption by the intestine, helping to control blood sugars and preventing obesity, colon cancer, and others diseases $[77,78]$.

In addition to chicory roots, inulin can be found in some cereals, such as rye, barley, and wheat [62-65]. Barley is among the most important cereals in the world after wheat, maize, and rice, and it is widely used as animal feed or as a raw material for brewing beer [79]. According to the USDA [16], the top five barley producers in 2021 were the European Union, Russia, Australia, Ukraine, and Canada, as shown in Figure 12.
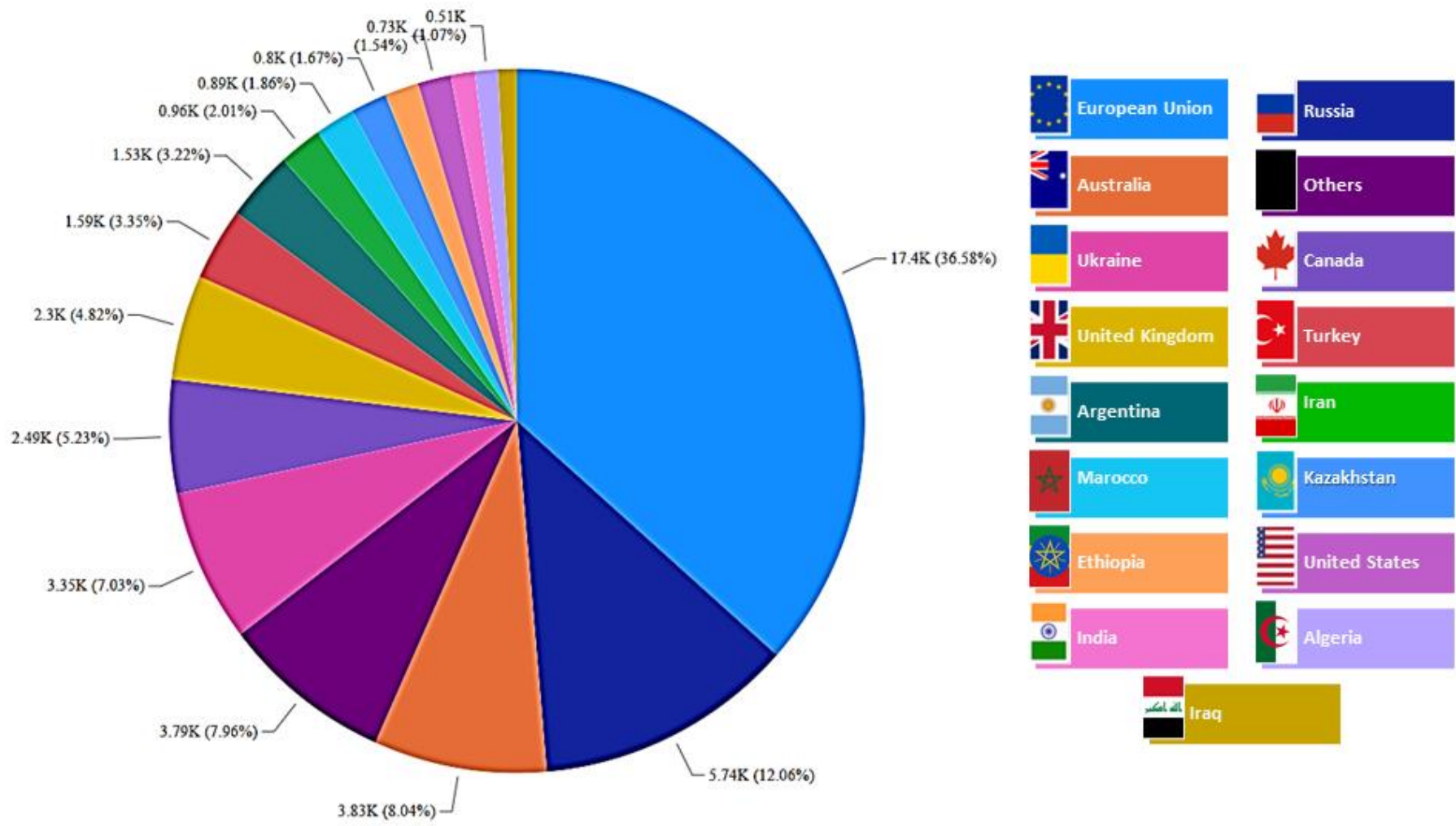

Figure 12. Main barley-producing countries in 2020 (thousand metric tons).

Industrially, barley is either milled or malted, in which it goes to the beer industries for beverage production [38]. Barley bagasse is considered a problem by beverage industries since a large amount of residues is produced daily and needs to be discarded without harming the environment. The most common residue from processing in beer industries is Brewer's spent grain (BSG), constituting around $85 \%(w / w)$ of the total by-products produced during beer production [80]. BSG can comprise up to $31 \%$ of the original malt weight, and $100 \mathrm{~L}$ of brewed beer produces close to $20 \mathrm{~kg}$ of wet BSG as side streams [80]. Its composition is diverse because its include a mixture of different original barley grain parts, e.g., husk, pericarp, endosperm pieces, and seed coats [80]. Since inulin content in barley can reach up to $1.5 \%$, it is possible to assume that the BSG residues are great sources for the extraction of this polysaccharide, thus contributing to reducing waste disposal and preventing economic losses [75].

Biotechnological applications involving the use of inulin are interesting in the biomedical area, especially for nutritional or pharmaceutical purposes. For nutraceutical benefits, 
inulin is used to replace fats and sugars, thus enabling the production of foods with fewer calories, such as ice cream and floury foods $[62,67,81]$. This is due to inulin's ability to pass through the digestive system without being metabolized, thus allowing for the production of functional dietary foods [62]. There have been many studies on the extraction of fructans, though reports regarding the optimization of extraction conditions are scarce. Inulin has been used as an ingredient in bioactive functional foods to promote the appearance of bifid and other beneficial microorganisms, thus leading to a healthy effect for humans through gut microbiota [82]. In the pharmaceutical industry, it is used as a bioactive carrier. In this case, inulin can act to prevent drug degradation in the upper gastrointestinal tract and facilitate transport to its last segment, thus preventing early degradation [62]. In this mechanism, upon reaching the colon, inulin is fermented by bacteria from the local microbiome, contributing to the increased absorption of minerals and food ions $[64,83]$.

Although the production and application of inulin are already widespread in some countries, its use is still very restricted in Brazil. As it is not produced in the domestic market, inulin must be imported, which makes it an expensive ingredient and makes its application difficult. To make its use more accessible to local industries, studies and investments into facilities are needed to implement an inulin production process in Brazil. The global market for inulin is mainly controlled by two big companies. The first is the BENEO $^{\text {TM }}$ Group, part of the Südzucker group, one of the leading companies in the food industry, which was formed in 2007 when Orafti, Palatinit, and Remy got together [84]. It currently has forty sugar mills and two refineries, including one located in Chile. The second is the Belgian company COSUCRA Groupe Warcoing [85]. Both companies operate in the markets of Belgium, Holland, and Germany; supplier countries with high per capita income of Europe and North America; and, recently, Asian countries such as Japan. There are other companies in France, Mexico, China, and India who participate in this market but do not have leading roles [86]. BENEO, one of the main producers of functional ingredients, announced an expansion of its chicory root inulin production plant in Chile by 2022, based on an investment of more than 50 million euros, after which there will be an increase of $20 \%$ in overall volume. This decision was a consequence of the growing demand for BENEO chicory root fibers, inulin, and oligofructose, as consumer interest in digestive health has grown [86].

\subsection{Pectin}

Pectin is a biocompatible, high molecular-weight, anionic and naturally occurring heteropolysaccharide present in terrestrial plants that is associated with celluloses, hemicelluloses, and lignin $[87,88]$. It can comprise up to one third of the cell walls in dicotyledonous and some monocotyledonous plants, but it is also found in smaller amount (2-10\%) in the cell walls of grass and wood tissue [87]. Pectin is mainly composed of galacturonic acid units, and it can vary in composition, structure, and molecular weight depending of its source and processing conditions [88]. Apple pomace, citrus, sugar beet pulp, grape, pineapple, and mango peel can be cited as residue sources for obtaining pectin [13,89-91]. However, the number of sources for industrial use has been limited for the first three materials [92].

The numerous biotechnological applications reported for pectin have allowed for the recent growth of interest in this area. Due to its good safety and low toxicity profile, pectin can be applied with simple methods, such as ionotropic gelation, for gel formation [87-89]. In this case, pectin concentration and molecular weight are proportional to the viscosity of the formed gel since more reaction sites are found in longer molecular chains [87]. The pectin market represents 45,000 tons yearly, and around 6300 tons of commercial pectin are used worldwide in the food industry, where it can be supplied in solid and particulate forms, similar to conventional sugar $[89,93]$.

It can also be used in the pharmaceutical and food industries as a thickening agent, rheology modifier, and an emulsifier in the production of jams, sweets, and desserts [87,88]. Generally, pectin has similar applications to other polysaccharides to produce pharma- 
ceuticals, cosmetics, and food coating products with functional, antimicrobial, biological, and active properties [88,94]. Pectin is capable of associating with other biopolymers to form microparticles, nanoparticles, or filmogenic solutions for food packaging design due to its anionic characteristic and gelling properties [95-97]. In biomedical products, pectin acts as a carrier for the delivery of certain medications used in wound healers and tissue engineering, in cholesterol reduction, as a probiotic agent, in anti-cancer therapies, in the manufacturing of contact lens membranes, in artificial corneas, and in catheters [88,98-100]. Pectin can also be applied to treat or prevent poisoning by toxic substances, e.g., mercury, because the functional groups present in its polymer chains can form complexes with metals, thus allowing for its use as a bio(nano)sorbent for the selective elimination of heavy metal [88,101].

Chemically, pectin chains can be divided into anionic and non-ionic side chains known as "smooth regions" and "hairy regions", respectively [13]. Pectin is a linear poly-galacturonic acid with different esterification degrees, either highly esterified by a methyl group (HMP - high methoxyl pectin, $>50 \%$ ) or only partially esterified (LMPlow methoxyl pectin, $<50 \%$ ), that can influence its emulsifying, texturizing, and gelling properties [13,87]. HMPs have been commonly used in food industries as thickeners and gelling agents, where large amounts of sugars are required for gelation, while LMPs are used to form low sugar-content jams [13]. Moreover, pectin can be divided into homogalacturonan and rhamnogalacturonan I and II, which differ due to the sugar linked in the $\beta-1,2$ and $\beta-1,4$ chains $[13,87]$. The primary structure of pectin defines the interactions of this macromolecule with solvents, though when it is switched into a helical structure, the intermolecular interactions lead to the formation of a different arrangement and result in complexes and viscous solutions formed by secondary structures [13]. The presence of carboxyl and hydroxyl groups confer hydrophilic and biodegradable characteristics to this polysaccharide $[13,87]$. The main functional groups in pectin chain are hydroxyl, amide, carboxyl, and methyl, and the hydrogen and ionic bonds interchain interactions have important roles in gel formation [13,87].

Pectin is easily obtained through simple extractive methods such as the use of hot water and a solvent with an acidic $\mathrm{pH}$ of around 2 that generates a fibrous concentrate, which can be pressed and washed to obtain a crude extract [92]. Extraction yields can be around $70 \%$, though other methods such as superfluid critical extraction, ultrasound-assisted extraction, and microwave-assisted extraction can be used to achieve higher values [92]. The species, extraction method, and storage conditions can change the chemical composition of pectin $[13,87,92]$. Compared to cellulose and chitosan, pectin has a more complex chemical structure that contributes to its biomedical effects. We analyzed journal publications from the last 20 years and found that chitosan has a higher number of publications (55\%), followed by cellulose $(18 \%)$, and pectin $(3 \%)$. The number of patents filed followed a similar sequence: cellulose $(38 \%)>$ chitosan $(24 \%)>$ pectin $(6 \%)$ [90].

\subsection{Chitin/Chitosan}

Food residues of animal origin are relevant sources of bioactive chemical substances. Seafood processing, especially that of crustaceans such as shrimp, crab, and lobster, generates a volume around $50-70 \%$ of waste [102]. Worldwide, the annual production of residues from the harvest of crustaceans is estimated at about 3.14 million tons [103,104]. Chitin is the second most abundant polysaccharide found in nature after cellulose [103,105]. Chitin's non-toxicity and biocompatibility contribute to its application in different fields [106-108]. In addition to seafood, chitin/chitosan can also be extracted from insects and some fungi species $[109,110]$. Mainly, to produce one kilogram of chitin with conventional chemical processes, close to $30 \mathrm{~kg}$ of shrimp shells (on a wet basis) are needed, whereas to produce one kilogram of chitosan, up to $1.5 \mathrm{~kg}$ of chitin, together with several acid and alkaline substances, are necessary [103].

Chemically, chitin is a long-chain polymer similar to cellulose but with acetyl amine groups replacing hydroxyl groups, thus making it a direct precursor to chitosan $[103,105,106]$. 
Chitin is a water-insoluble polysaccharide due to the intra- and intermolecular hydrogen bonds formed by the oxygen of acetamido group with adjacent $-\mathrm{NH}$ or $-\mathrm{OH}$ functions groups [110]. Moreover, the N-acetylation degree among chitin's chains also has a significant effects on water-insolubility, limiting swelling properties and thus its industrial applications [110]. Chitin can occur as $\alpha$ and $\beta$ allomorphs, though the $\alpha$-chitin form is the most abundant and the $\beta$-chitin form is rarely found to be associated with proteins in squid pens and synthesized by pogonophoran and vestimentiferan worms [111]. The three different crystalline phases differ in the orientation of their microfibrils, making their applicability versatile for the production of different functional materials, such as for pharmacological, anti-inflammatory, antimicrobial, and immunological purposes [103,105,106].

Chitin's conventional extraction and deacetylation to form chitosan have many drawbacks, especially linked to harmful effects in the physico-chemical properties of both biopolymers, leading to diverse molecular weight and acetylation degrees that can affect their functional properties; these include the utilization of harmful/toxic solvents, low processing yields, the generation of wastewater effluent containing toxic chemicals, and processing costs $[103,111]$. To overcome these difficulties, green techniques, such as those based on the use of deep eutectic solvents and ionic liquids, have been used as sustainable alternatives $[103,111]$. As described for other polysaccharides obtained from residues, the molecular weight and the degree of deacetylation play important roles in the biological functions of chitin, e.g., higher degrees of deacetylation promote greater responses. The physicochemical characteristics of chitin and chitosan can vary by source and seasonality of raw materials, as well as other factors intrinsic to processing methods [111].

Chitosan, on the other hand, is a deacetylated derivative of chitin that can be processed into different materials such as membranes, sponges, gels, nanoparticles, and nanofibers $[103,105]$. The differentiation of chitin and chitosan can be seen in the degree of deacetylation: if it is higher than $50 \%$ mol, it is classified as chitosan [103,111]. Chitosan is water-soluble at a mild acidic $\mathrm{pH}$ of around 4.5, which facilitates its biological application and solubilization, while chitin is only soluble in concentrated acid solutions [103,105,106]. Due to the limited applications of pure chitosan, techniques can be used to improve its selectivity, functionalizing its structure with chemical reactions and cross-linking to several molecules for industrial uses [103,105,106].

Both chitin and chitosan are known in biomedical areas for drug delivery. Both biopolymers act in the removal of allergenic proteins from some foods, the controlled transfer of drugs, and food supplements with hypocholesterolemic effects, among others $[103,105,106]$. They are also used as antibacterial, anti-inflammatory, sunscreen, and anti-aging cosmetics, as well as in tissue engineering where they aid in the reconstructive and healing processes of epithelial tissues [112-114]. In food technology, chitosan has a wide range of applications, such as acting in the extension of food shelf-life, e.g., for bread and apples, because it can reduce starch retrogradation and inhibit microbial growth in both food preparation and the production of coating packaging with bioactive properties $[103,115,116]$. The production of coatings occurs due to the association of chitosan with other compounds with biotechnological action, and this is mainly pursued to overcome some of chitosan's technological limitations, such as its brittleness, low elongation, and flexibility [103]. For example, by combining chitosan with poly(vinyl) alcohol and lignin nanoparticles or with other polysaccharides to form composite coatings, greater plastic resistance compared to that of individual components can be achieved [112,117,118].

For benchmark market values of these isolated compounds, those of the "GTC Bio Corporation" company in China can be highlighted, with diverse prices and different levels of quality. The price of chitin is around $\$ 23.4 / \mathrm{Kg}$, and it can range from $\$ 21.06$ to $52.65 / \mathrm{Kg}$ for chitosan due different purity degrees [119]. In the production of functional materials, chitin has stood out in the manufacturing of hydrogels, aerogels, membranes, films, and fibers. Since chitosan has a quick biodegradability (less than 1 month) in different sites compared to the 300 years of the conventional plastic use, it can replace products that use petroleum-based plastics [103,119-122]. 


\subsection{Hyaluronic Acid (HA)}

Hyaluronic acid is a naturally occurring polymer commonly found in animal tissues, including residual ones such as vitreous humors, chicken crests, and fish eyeballs, or in the cell walls of some bacteria such as Streptococcus zooepidemicus [123-125] Chemically, it is composed of a major glycosaminoglycan macromolecule with alternating $\beta-1,3$ and $\beta-1,4$ glycosidic linkages from a family of linear, anionic, hetero-co-polysaccharides [124,125]. The repeating units of $\beta(1,4)$-glucuronic acid (GlcUA)- $\beta(1,3)-\mathrm{N}$-acetylglucosamine (GlcNAc) in HA generally adopt a stable chair conformation, while in solution highly flexible regions may exhibit a random coil structures [126]. Besides hyaluronic acid, the main glycosaminoglycans largely diffused in the epithelial, connective, and nervous tissues of vertebrated animals are chondroitin sulfate, dermatan sulfate, keratin sulfate, heparin sulfate, and heparin [123]. HA is highly hydrophilic due to the presence of hydroxyl groups among chains that can bind water molecules, and this trait is linked to its greatest asset: allowing for tissue flexibility [124]. As a result, it can also be applied in the development of pro-drugs with better physicochemical properties, stability, and optimized therapeutic efficacy compared to free drugs $[123,124]$.

Industrial extraction predominantly consists of the isolation of HA from chicken crests residues, although some microbial fermentation is also applied [124]. For the purity of this substance, free from contaminating agents, chickens should be selected to avoid cross-contamination $[124,125]$. It is estimated that the global market for HA will reach a worldwide value of around US $\$ 15.4$ billion by 2025 , and it will be dominated by nine international brands, mainly due to its cosmetic applications [123,127].

Table 3 presents different concentrations of HA extracted from livestock industry residues. The studies referenced in this table were initiated back in the 1980s and used optimization methods to industrially obtain HA from slaughtered chicken crests. Over a period of 10 years, an academic effort to experimentally improve the extraction performance of HA was noted; however, not all livestock residues were found to have significant volumes and have been used for the extraction of hyaluronic acid.

Table 3. Hyaluronic acid content from different sources.

\begin{tabular}{cccc}
\hline Source & Residues & Content & Reference \\
\hline Swine & & $0.04 \mathrm{~g} \mathrm{~L}^{-1}$ of vitreous humor & \\
Swordfish & & $0.055 \mathrm{~g} \mathrm{~L}^{-1}$ of vitreous humor & {$[128]$} \\
Sharks & Eyes & $0.3 \mathrm{~g} \mathrm{~L}^{-1}$ of vitreous humor & \\
Tuna fish & & $0.42 \mathrm{~g} \mathrm{~L}^{-1}$ of vitreous humor & {$[129]$} \\
Bovines & & $0.47 \mathrm{~g} \mathrm{~L}^{-1}$ of vitreous humor & {$[130]$} \\
& & $1.0 \mathrm{mg} \mathrm{g}^{-1}$ of crest & {$[131]$} \\
Chickens & Crests & $39.8 \mathrm{mg} \mathrm{g}^{-1}$ of crest & {$[132]$} \\
& & $15.0 \mathrm{mg} \mathrm{g}^{-1}$ of crest & {$[133]$} \\
\hline
\end{tabular}

The biomedical applications of hyaluronic acid include its use in ocular and plastic surgery, the treatment of osteoarthritis, corneal xerosis in anti-aging products, and tissue culture, as well as in carriers for different osteo-inductive or osteogenic components $[123,124,132]$. HA has been also applied for a wide range of pharmaceutical purposes, such as the design of nanoparticles, microparticles, microspheres, gels, polyplexes, liposomes, micelles, and implants [124,132]. Good experimental results were found when HA was applied as wound dressings and chronic ulcers in the form of nanocomposites combined with different biopolymers, highlighting HA's biomedical application [131,132]. Applications in drug delivery include matrices for the treatment of skin infections, cancer therapy, and controlled release of proteins, antiseptics, and antibiotics via different routes, e.g., skin, ocular, topical, nasal, and oral routes [134]. Additionally, from a therapeutic point of view, HA is among the most studied biomaterials for cartilage regeneration $[123,132,134]$. A potential approach to cartilage repair is the transplantation of autologous chondrocytes or stem cells into cartilage defects using a natural or synthetic framework [134]. To perform 
the cartilage repair function, the component must be biocompatible with cartilage tissue, biodegradable, non-toxic, and non-immunogenic, which are relevant characteristics of biopolymers such as HA and chitosan [131,132,134].

Researchers have studied an interesting experimental application of this glycosaminoglycan in the modulation of the immune system to inhibit inflammation and alter the chemotactic factor and the stimulation of cytokine release, in order to maintain the balance between type 1 and $2 \mathrm{~T}$ helpers (Th) $[135,136]$. Recent studies have also shown that plantderived hyaluronic acid can effectively modulate macrophage proliferation and promote its phagocytic function in response to foreign bodies and tumor cells [136]. Due to its high hydrophilicity, hyaluronic acid can also prolong drugs action time at target sites, and it can naturally interact with CD44 membrane receptors that are overexpressed in different types of cancer and other pathologies, which is promising for their treatment [136].

\section{Conclusions}

Agro-industrial residues are widely distributed all over the world through local trade, importation, and exportation, thus making it possible to implement novel techniques to optimize these resources in different industries. Biomass resulting from agroindustrial processes offer alternatives for obtaining diverse chemical ingredients. In this study, the presented polysaccharides were obtained from the most important worldwide agro-industrial residues, which have been highlighted as materials that may reshape biorefineries around the world. Far beyond biofuels, obtaining, purifying, and combining these isolated molecules to high-value innovative applications have been presented as ways to develop the bioeconomy. All the studied polysaccharides have similar applications in the pharmaceutical industry as carriers of drugs and medicines and in the production of materials, functional foods, nutraceuticals, and cosmetics, though with different mechanisms.

The abundance of animal and plant biomass allows for the estimation of the number of polysaccharide-rich residues, as shown in this study. The extraction of cellulose has great potential due to the huge volume of imported and exported residues based on major crops such as rice, wheat, and maize. The major producers of these crops are also the main generators of their residues. The United States and China are the main producers of cellulosic-waste production from maize, while China and India are those from rice, and the European Union and China are those from wheat. Thus, China dominates the production of cellulosic waste from these crops. Moreover, China is also the predominant country in the chemical industry, with international suppliers of these five isolated compounds. Animal residues from seafood and livestock industries, such as crustacean shells, fish eyeballs, and chicken crests, are major sources for the extraction of chitin, chitosan, and hyaluronic acid, respectively. Plant residues, e.g., citrus waste and chicory roots, have been extensively used in pectin extraction and (at a minor proportion) inulin obtainment.

Many studies have focused on the use of agro-industrial biomass residues only to obtain energy through pyrolysis, fermentation, or thermoelectric processes. However, it has been shown that this path that in contrary to the concept of sustainability, since other sources of energy, e.g., solar and wind energy, are abundant and available for utilization. It is necessary to increase the use of agro-industrial residues as a source of valuable materials for industrial use and in the isolation of polysaccharides with properties capable of producing bioactive natural products.

Author Contributions: Conceptualization, V.F.V.-J.; methodology, V.F.V.-J.; formal analysis, M.A.d.S., B.E.T.-C. and V.F.V.-J.; investigation, M.A.d.S., I.T.V.-B., J.M.L.-d.-S., P.d.N.A. and V.F.V.-J.; resources, V.F.V.-J.; writing-original draft preparation, M.A.d.S., I.T.V.-B., J.M.L.-d.-S., P.d.N.A., B.E.T.-C. and V.F.V.-J; writing-review and editing, M.A.d.S., I.T.V.-B., J.M.L.-d.-S., P.d.N.A., B.E.T.-C. and V.F.V.-J.; visualization, J.M.L.-d.-S. and V.F.V.-J.; supervision, M.A.d.S., B.E.T.-C. and V.F.V.-J.; project administration, M.A.d.S. and V.F.V.-J. All authors have read and agreed to the published version of the manuscript. 
Funding: This research received no external funding.

Institutional Review Board Statement: Not applicable.

Informed Consent Statement: Not applicable.

Data Availability Statement: Not applicable.

Conflicts of Interest: The authors declare no conflict of interest.

\section{References}

1. FAO. The State of Food and Agriculture 2019. Moving Forward on Food Loss and Waste Reduction; FAO-Food and Agriculture Organization of the United Nations: Rome, Italy, 2019.

2. Campos, D.A.; Gómez-García, R.; Vilas-Boas, A.A.; Madureira, A.R.; Pintado, M.M. Management of Fruit Industrial By-ProductsA Case Study on Circular Economy Approach. Molecules 2020, 25, 320. [CrossRef]

3. Zuin, V.G.; Ramin, L.Z. Green and Sustainable Separation of Natural Products from Agro-Industrial Waste: Challenges, Potentialities, and Perspectives on Emerging Approaches. Top. Curr. Chem. 2018, 376, 3-57. [CrossRef]

4. Amran, M.A.; Palaniveloo, K.; Fauzi, R.; Satar, N.M.; Mohidin, T.B.M.; Mohan, G.; Razak, S.A.; Arunasalam, M.; Nagappan, T.; Seelan, J.S.S. Value-Added Metabolites from Agricultural Waste and Application of Green Extraction Techniques. Sustainability 2021, 13, 11432. [CrossRef]

5. Kruijssen, F.; Tedesco, I.; Ward, A.; Pincus, L.; Love, D.; Thorne-Lyman, A.L. Loss and Waste in Fish Value Chains: A Review of the Evidence from Low and Middle-Income Countries. Glob. Food Sec. 2020, 26, 100434. [CrossRef]

6. Sagar, N.A.; Pareek, S.; Sharma, S.; Yahia, E.M.; Lobo, M.G. Fruit and Vegetable Waste: Bioactive Compounds, Their Extraction, and Possible Utilization. Compr. Rev. Food Sci. Food Saf. 2018, 17, 512-531. [CrossRef]

7. United Nations. The 17 Goals-The United Nations Sustainable Development Goals. Available online: https://sdgs.un.org/ (accessed on 26 September 2021).

8. Tuck, C.O.; Pérez, E.; Horváth, I.T.; Sheldon, R.A.; Poliakoff, M. Valorization of Biomass: Deriving More Value from Waste. Science 2012, 337, 695-699. [CrossRef] [PubMed]

9. Kumar, K.; Yadav, A.N.; Kumar, V.; Vyas, P.; Dhaliwal, H.S. Food Waste: A Potential Bioresource for Extraction of Nutraceuticals and Bioactive Compounds. Bioresour. Bioprocess. 2017, 4, 18. [CrossRef]

10. Trigo, J.P.; Alexandre, E.M.C.; Saraiva, J.A.; Pintado, M.E. High Value-Added Compounds from Fruit and Vegetable by-ProductsCharacterization, Bioactivities, and Application in the Development of Novel Food Products. Crit. Rev. Food Sci. Nutr. 2020, 60, 1388-1416. [CrossRef]

11. Grasso, S. Extruded Snacks from Industrial By-Products: A Review. Trends Food. Sci. Technol. 2020, 99, 284-294. [CrossRef]

12. Comunian, T.A.; Silva, M.P.; Souza, C.J.F. The Use of Food By-Products as a Novel for Functional Foods: Their Use as Ingredients and for the Encapsulation Process. Trends Food Sci. Technol. 2021, 108, 269-280. [CrossRef]

13. Mellinas, C.; Ramos, M.; Jiménez, A.; Garrigós, M.C. Recent Trends in the Use of Pectin from Agro-Waste Residues as a Natural-Based Biopolymer for Food Packaging Applications. Materials 2020, 13, 673. [CrossRef]

14. Liu, H.; Xie, M.; Nie, S. Recent Trends and Applications of Polysaccharides for Microencapsulation of Probiotics. Food Front. 2020, 1, 45-59. [CrossRef]

15. Rivas, M.Á.; Casquete, R.; Martín, A.; Córdoba, M.d.G.; Aranda, E.; Benito, M.J. Strategies to Increase the Biological and Biotechnological Value of Polysaccharides from Agricultural Waste for Application in Healthy Nutrition. Int. J. Environ. Res. Public Health 2021, 18, 5937. [CrossRef]

16. USDA-Foreign Agricultural Service. United States Department of Agriculture. Available online: https://apps.fas.usda.gov/ psdonline/app/index.html\#/app/downloads (accessed on 29 September 2021).

17. Seddiqi, H.; Oliaei, E.; Honarkar, H.; Jin, J.; Geonzon, L.C.; Bacabac, R.G.; Klein-Nulend, J. Cellulose and Its Derivatives: Towards Biomedical Applications. Cellulose 2021, 28, 1893-1931. [CrossRef]

18. Fact.MR. Polysaccharides and Oligosaccharides Market. Available online: https://www.factmr.com/report/427/polysaccharidesoligosaccharides-market (accessed on 23 December 2021).

19. Popović, S.; Hromiš, N.; Šuput, D.; Bulut, S.; Romanić, R.; Lazić, V. Valorization of By-Products from the Production of Pressed Edible Oils to Produce Biopolymer Films. In Cold Pressed Oils; Ramadan, M.F., Ed.; Elsevier: Amsterdam, The Netherlands, 2020; pp. 15-30. [CrossRef]

20. Bello, B.; Mustafa, S.; Tan, J.S.; Ibrahim, T.A.T.; Tam, Y.J.; Ariff, A.B.; Manap, M.Y.; Abbasiliasi, S. Evaluation of the Effect of Soluble Polysaccharides of Palm Kernel Cake as a Potential Prebiotic on the Growth of Probiotics. 3 Biotech 2018, 8, 346. [CrossRef] [PubMed]

21. Fernandes, P.A.R.; Silva, A.M.S.; Evtuguin, D.V.; Nunes, F.M.; Wessel, D.F.; Cardoso, S.M.; Coimbra, M.A. The Hydrophobic Polysaccharides of Apple Pomace. Carbohydr. Polym. 2019, 223, 115132. [CrossRef] [PubMed]

22. Suhas; Gupta, V.K.; Carrott, P.J.M.; Singh, R.; Chaudhary, M.; Kushwaha, S. Cellulose: A Review as Natural, Modified and Activated Carbon Adsorbent. Bioresour. Technol. 2016, 216, 1066-1076. [CrossRef]

23. Baghaei, B.; Skrifvars, M. All-Cellulose Composites: A Review of Recent Studies on Structure, Properties and Applications. Molecules 2020, 25, 2836. [CrossRef] [PubMed] 
24. Alzate-Arbeláez, A.F.; Dorta, E.; López-Alarcón, C.; Cortés, F.B.; Rojano, B.A. Immobilization of Andean Berry (Vaccinium Meridionale) Polyphenols on Nanocellulose Isolated from Banana Residues: A Natural Food Additive with Antioxidant Properties. Food Chem. 2019, 294, 503-517. [CrossRef]

25. Kallel, F.; Bettaieb, F.; Khiari, R.; García, A.; Bras, J.; Chaabouni, S.E. Isolation and Structural Characterization of Cellulose Nanocrystals Extracted from Garlic Straw Residues. Ind. Crops Prod. 2016, 87, 287-296. [CrossRef]

26. Motaung, T.E.; Mtibe, A. Alkali Treatment and Cellulose Nanowhiskers Extracted from Maize Stalk Residues. Mater. Sci. Appl. 2015, 6, 1022-1032. [CrossRef]

27. Coelho, C.C.S.; Michelin, M.; Cerqueira, M.A.; Gonçalves, C.; Tonon, R.V.; Pastrana, L.M.; Freitas-Silva, O.; Vicente, A.A.; Cabral, L.M.C.; Teixeira, J.A. Cellulose Nanocrystals from Grape Pomace: Production, Properties and Cytotoxicity Assessment. Carbohydr. Polym. 2018, 192, 327-336. [CrossRef] [PubMed]

28. Szymańska-Chargot, M.; Chylińska, M.; Gdula, K.; Kozioł, A.; Zdunek, A. Isolation and Characterization of Cellulose from Different Fruit and Vegetable Pomaces. Polymers 2017, 9, 495. [CrossRef] [PubMed]

29. Widiarto, S.; Yuwono, S.D.; Rochliadi, A.; Arcana, I.M. Preparation and Characterization of Cellulose and Nanocellulose from Agro-Industrial Waste-Cassava Peel. IOP Conf. Ser. Mater. Sci. Eng. 2017, 176, 012052. [CrossRef]

30. Reddy, J.P.; Rhim, J.-W. Extraction and Characterization of Cellulose Microfibers from Agricultural Wastes of Onion and Garlic. J. Nat. Fibers 2018, 15, 465-473. [CrossRef]

31. Valdebenito, F.; Pereira, M.; Ciudad, G.; Azocar, L.; Briones, R.; Chinga-Carrasco, G. On the Nanofibrillation of Corn Husks and Oat Hulls Fibres. Ind. Crops Prod. 2017, 95, 528-534. [CrossRef]

32. Li, P.; Wang, Y.; Hou, Q.; Li, X. Isolation and Characterization of Microfibrillated Cellulose from Agro-Industrial Soybean Residue (Okara). BioResources 2018, 13, 7944-7956. [CrossRef]

33. Collazo-Bigliardi, S.; Ortega-Toro, R.; Chiralt Boix, A. Isolation and Characterisation of Microcrystalline Cellulose and Cellulose Nanocrystals from Coffee Husk and Comparative Study with Rice Husk. Carbohydr. Polym. 2018, 191, 205-215. [CrossRef]

34. Kampeerapappun, P. Extraction and Characterization of Cellulose Nanocrystals Produced by Acid Hydrolysis from Corn Husk. J. Met. Mater. Miner. 2015, 25, 19-26. [CrossRef]

35. Associação Brasileira de Indústrias da Biomassa-ABIB. Inventário Residual Brasil. 2011. Available online: https:/ / pt.calameo. com/accounts/200968 (accessed on 27 August 2021).

36. Ranum, P.; Peña-Rosas, J.P.; Garcia-Casal, M.N. Global Maize Production, Utilization, and Consumption. Ann. N. Y. Acad. Sci. 2014, 1312, 105-112. [CrossRef]

37. Fărcas, A.; Drețcanu, G.; Pop, T.D.; Enaru, B.; Socaci, S.; Diaconeasa, Z. Cereal Processing By-Products as Rich Sources of Phenolic Compounds and Their Potential Bioactivities. Nutrients 2021, 13, 3934. [CrossRef] [PubMed]

38. ElMekawy, A.; Diels, L.; De Wever, H.; Pant, D. Valorization of Cereal Based Biorefinery Byproducts: Reality and Expectations. Environ. Sci. Technol. 2013, 47, 9014-9027. [CrossRef]

39. Langton, M.; Gutiérrex, J.L.V. The Structure of Cereal Grains and Their Products. In Whole Grains and Health; Landberg, R., Scheers, N., Eds.; Wiley: New York, NY, USA, 2021; pp. 1-20. [CrossRef]

40. Steph Wright. Largest Rice-Producing Countries. Available online: https://www.worldatlas.com/articles/largest-rice-producingcountries.html (accessed on 27 December 2021).

41. Juliano, B.O.; Tuaño, A.P.P. Gross Structure and Composition of the Rice Grain. In Rice-Chemistry and Technology; Bao, J.S., Ed.; Elsevier Inc.: Amsterdam, The Netherlands, 2019; pp. 31-53. [CrossRef]

42. Goodman, B.A. Utilization of Waste Straw and Husks from Rice Production: A Review. J. Bioresour. Bioprod. 2020, 5, 143-162. [CrossRef]

43. Reddy, N.; Yang, Y. Properties of High-Quality Long Natural Cellulose Fibers from Rice Straw. J. Agric. Food Chem. 2006, 54, 8077-8081. [CrossRef] [PubMed]

44. Nuttall, J.G.; O’Leary, G.J.; Panozzo, J.F.; Walker, C.K.; Barlow, K.M.; Fitzgerald, G.J. Models of Grain Quality in Wheat-A Review. F. Crop. Res. 2017, 202, 136-145. [CrossRef]

45. Balkovič, J.; van der Velde, M.; Skalský, R.; Xiong, W.; Folberth, C.; Khabarov, N.; Smirnov, A.; Mueller, N.D.; Obersteiner, M. Global Wheat Production Potentials and Management Flexibility under the Representative Concentration Pathways. Glob. Planet. Chang. 2014, 122, 107-121. [CrossRef]

46. Prückler, M.; Siebenhandl-Ehn, S.; Apprich, S.; Höltinger, S.; Haas, C.; Schmid, E.; Kneifel, W. Wheat Bran-Based Biorefinery 1: Composition of Wheat Bran and Strategies of Functionalization. Food Sci. Technol. 2014, 56, 211-221. [CrossRef]

47. Gabiatti, C.; Neves, I.C.O.; Lim, L.-T.; Bohrer, B.M.; Rodrigues, R.C.; Prentice, C. Characterization of Dietary Fiber from Residual Cellulose Sausage Casings Using a Combination of Enzymatic Treatment and High-Speed Homogenization. Food Hydrocoll. 2020, 100, 105398. [CrossRef]

48. Riaz, A.; Lagnika, C.; Luo, H.; Nie, M.; Dai, Z.; Liu, C.; Abdin, M.; Hashim, M.M.; Li, D.; Song, J. Effect of Chinese Chives (Allium Tuberosum) Addition to Carboxymethyl Cellulose Based Food Packaging Films. Carbohydr. Polym. 2020, 235, 115944. [CrossRef] [PubMed]

49. Aziz, T.; Ullah, A.; Fan, H.; Ullah, R.; Haq, F.; Khan, F.U.; Iqbal, M.; Wei, J. Cellulose Nanocrystals Applications in Health, Medicine and Catalysis. J. Polym. Environ. 2021, 29, 2062-2071. [CrossRef]

50. Gupta, R.D.; Raghav, N. Nano-Crystalline Cellulose: Preparation, Modification and Usage as Sustained Release Drug Delivery Excipient for Some Non-Steroidal Anti-Inflammatory Drugs. Int. J. Biol. Macromol. 2020, 147, 921-930. [CrossRef] [PubMed] 
51. Costa, S.A.; Cerón, A.A.; Petreca, B.B.; Costa, S.M. Fibers of Cellulose Sugarcane Bagasse with Bromelain Enzyme Immobilized to Application in Dressing. SN Appl. Sci. 2020, 2, 285. [CrossRef]

52. USDA-Foreign Agricultural Service. Corn. Available online: https:/ /www.fas.usda.gov/commodities/corn (accessed on 27 December 2021).

53. USDA-Foreign Agricultural Service. Argentina: Argentine Government Announces New Wheat and Corn Export Quotas. Available online: https://www.fas.usda.gov/data/argentina-argentine-government-announces-new-wheat-and-corn-exportquotas (accessed on 27 December 2021).

54. Food and Agriculture Organization of the United Nations-FAO. Brazil Set to Become the Second Largest Global Exporter of Maize, Says FAO. Available online: https:/ /www.fao.org/americas/noticias/ver/pt/c/1194125/ (accessed on 27 December 2021).

55. Reuters. Analysis: India May Corner Nearly Half of Global Rice Trade as Exports Soar to Record. Available online: https: //www.reuters.com/world/india/india-may-corner-nearly-half-global-rice-trade-exports-soar-record-2021-09-16/ (accessed on 27 December 2021).

56. Bhattacharjee, P.; Singhal, R.S.; Kulkarni, P.R. Basmati Rice: A Review. Int. J. Food Sci. Technol. 2002, 37, 1-12. [CrossRef]

57. Prom-u-thai, C.; Rerkasem, B. Rice Quality Improvement. A Review. Agron. Sustain. Dev. 2020, 40, 28. [CrossRef]

58. The Economic Times. Vietnam-The Third Biggest Exporter of Rice-Buys from India for the First Time in Decade. Available online: https:/ / economictimes.indiatimes.com/news/economy/foreign-trade/vietnam-the-third-biggest-exporter-of-rice-buysfrom-india-for-the-first-time-in-decades/articleshow /80101651.cms?from=mdr (accessed on 27 December 2021).

59. Storey, P. Thailand in Tight Race with Vietnam to be 2021's Second-Largest Global Rice Exporter. Available online: https:/ / www.spglobal.com/platts/pt/market-insights/latest-news/agriculture/112521-thailand-in-tight-race-with-vietnamto-be-2021s-second-largest-global-rice-exporter (accessed on 27 December 2021).

60. Shikha Singh. EU DATA: Wheat Exports Reach 16.37 Mil Mt, Corn Imports Seen at 3.4 Mil Mt. Available online: https:/ / www.spglobal.com/platts/en/market-insights/latest-news/agriculture/020821-eu-data-wheat-exports-reach1637-mil-mt-corn-imports-seen-at-34-mil-mt (accessed on 27 December 2021).

61. USDA-Foreign Agricultural Service. Wheat 2020 Export Highlights. Available online: https://www.fas.usda.gov/wheat-2020 -export-highlights (accessed on 27 December 2021).

62. Teferra, T.F. Possible Actions of Inulin as Prebiotic Polysaccharide: A Review. Food Front. 2021, 2, 407-416. [CrossRef]

63. Redondo-Cuenca, A.; Herrera-Vázquez, S.E.; Condezo-Hoyos, L.; Gómez-Ordóñez, E.; Rupérez, P. Inulin Extraction from Common Inulin-Containing Plant Sources. Ind. Crops Prod. 2021, 170, 113726. [CrossRef]

64. Mensink, M.A.; Frijlink, H.W.; van der Voort Maarschalk, K.; Hinrichs, W.L.J. Inulin, a Flexible Oligosaccharide I: Review of Its Physicochemical Characteristics. Carbohydr. Polym. 2015, 130, 405-419. [CrossRef] [PubMed]

65. Lima, E.C.D.S.; Manhães, L.R.T.; Santos, E.R.D.; Feijó, M.B.D.S.; Sabaa-Srur, A.U.D.O. Optimization of the Inulin Aqueous Extraction Process from the Açaí (Euterpe Oleracea, Mart.) Seed. Food Sci. Technol. 2021, 41, 884-889. [CrossRef]

66. Afinjuomo, F.; Abdella, S.; Youssef, S.H.; Song, Y.; Garg, S. Inulin and Its Application in Drug Delivery. Pharmaceuticals 2021, 14, 855. [CrossRef] [PubMed]

67. Miremadi, F.; Shah, N.P. Applications of Inulin and Probiotics in Health and Nutrition. Int. Food Res. J. 2012, 19, 1337-1350.

68. Lopes, S.M.S.; Krausová, G.; Carneiro, J.W.P.; Gonçalves, J.E.; Gonçalves, R.A.C.; de Oliveira, A.J.B. A New Natural Source for Obtainment of Inulin and Fructo-Oligosaccharides from Industrial Waste of Stevia Rebaudiana Bertoni. Food Chem. 2017, 225, 154-161. [CrossRef] [PubMed]

69. Cavini, S.; Guzzetti, L.; Givoia, F.; Regonesi, M.E.; Di Gennaro, P.; Magoni, C.; Campone, L.; Labra, M.; Bruni, I. Artichoke (Cynara Cardunculus Var. Scolymus L.) by-Products as a Source of Inulin: How to Valorise an Agricultural Supply Chain Extracting an Added-Value Compound. Nat. Prod. Res. 2020, in press. [CrossRef] [PubMed]

70. Escobar-Ledesma, F.R.; Sánchez-Moreno, V.E.; Vera, E.; Ciobotă, V.; Jentzsch, P.V.; Jaramillo, L.I. Extraction of Inulin from Andean Plants: An Approach to Non-Traditional Crops of Ecuador. Molecules 2020, 25, 5067. [CrossRef] [PubMed]

71. Stolze, A.; Wanke, A.; van Deenen, N.; Geyer, R.; Prüfer, D.; Schulze Gronover, C. Development of Rubber-Enriched Dandelion Varieties by Metabolic Engineering of the Inulin Pathway. Plant Biotechnol. J. 2017, 15, 740-753. [CrossRef] [PubMed]

72. Moreno-Mendoza, Y.; López-Villarreal, K.D.; Hernández-Martínez, C.A.; Rodríguez-Tovar, L.E.; Hernández-Coronado, A.C.; Soto-Domínguez, A.; Hume, M.E.; Méndez-Zamora, G. Effect of Moringa Leaf Powder and Agave Inulin on Performance, Intestinal Morphology, and Meat Yield of Broiler Chickens. Poult. Sci. 2021, 100, 738-745. [CrossRef] [PubMed]

73. Rafael Augustus de Oliveira, K.J.P.; Chiorato, M.; Park, K.J.B.; Nogueira, R.I. Optimization of Inulin Extraction from Chicory Roots. Rev. Bras. Prod. Agroind. 2004, 6, 131-140.

74. Chicory Root Powdered Inulin Extract. Available online: https://pt.made-in-china.com/tag_search_product/Inulin-Powder_ isyngorn_1.html (accessed on 27 August 2021).

75. Samolińska, W.; Grela, E.R. Comparative Effects of Inulin with Different Polymerization Degrees on Growth Performance, Blood Trace Minerals, and Erythrocyte Indices in Growing-Finishing Pigs. Biol. Trace Elem. Res. 2017, 176, 130-142. [CrossRef]

76. Usman, M.; Zhang, C.; Patil, P.J.; Mehmood, A.; Li, X.; Bilal, M.; Haider, J.; Ahmad, S. Potential Applications of Hydrophobically Modified Inulin as an Active Ingredient in Functional Foods and Drugs-A Review. Carbohydr. Polym. 2021, 252, 117176. [CrossRef] 
77. Tian, M.; Li, D.; Ma, C.; Feng, Y.; Hu, X.; Chen, F. Barley Leaf Insoluble Dietary Fiber Alleviated Dextran Sulfate Sodium-Induced Mice Colitis by Modulating Gut Microbiota. Nutrients 2021, 13, 846. [CrossRef] [PubMed]

78. Pop, O.L.; Vodnar, D.C.; Diaconeasa, Z.; Istrati, M.; Bințințan, A.; Bințințan, V.V.; Suharoschi, R.; Gabbianelli, R. An Overview of Gut Microbiota and Colon Diseases with a Focus on Adenomatous Colon Polyps. Int. J. Mol. Sci. 2020, 21, 7359. [CrossRef] [PubMed]

79. Fărcaş, A.C.; Socaci, S.A.; Dulf, F.V.; Tofană, M.; Mudura, E.; Diaconeasa, Z. Volatile Profile, Fatty Acids Composition and Total Phenolics Content of Brewers' Spent Grain by-Product with Potential Use in the Development of New Functional Foods. J. Cereal Sci. 2015, 64, 34-42. [CrossRef]

80. Steiner, J.; Procopio, S.; Becker, T. Brewer's Spent Grain: Source of Value-Added Polysaccharides for the Food Industry in Reference to the Health Claims. Eur. Food Res. Technol. 2015, 303-315. [CrossRef]

81. Shoaib, M.; Shehzad, A.; Omar, M.; Rakha, A.; Raza, H.; Sharif, H.R.; Shakeel, A.; Ansari, A.; Niazi, S. Inulin: Properties, Health Benefits and Food Applications. Carbohydr. Polym. 2016, 147, 444-454. [CrossRef] [PubMed]

82. Manso, J.; Mena, M.L.; Yáñez-Sedeño, P.; Pingarrón, J.M. Bienzyme Amperometric Biosensor Using Gold Nanoparticle-Modified Electrodes for the Determination of Inulin in Foods. Anal. Biochem. 2008, 375, 345-353. [CrossRef]

83. Gupta, N.; Jangid, A.K.; Pooja, D.; Kulhari, H. Inulin: A Novel and Stretchy Polysaccharide Tool for Biomedical and Nutritional Applications. Int. J. Biol. Macromol. 2019, 132, 852-863. [CrossRef] [PubMed]

84. BENEO. BENEO-Connecting Nutrition and Health. Available online: https:/ /www.beneo.com/ (accessed on 29 December 2021).

85. COSUCRA. Cosucra-Building Our Future with Nature. Available online: https://www.cosucra.com/ (accessed on 29 December 2021).

86. BENEO. Investe Mais de 50 Milhões de Euros Para Expandir Sua Produção de Inulina da Raiz de Chicória. Available online: http: / / www.revistait.com.br/noticias / destaque/beneo-investe-mais-de-50-milhoes-de-euros-para-expandir-sua-producaode-inulina-da-raiz-de-chicoria/ (accessed on 27 August 2021).

87. Chan, S.Y.; Choo, W.S.; Young, D.J.; Loh, X.J. Pectin as a Rheology Modifier: Origin, Structure, Commercial Production and Rheology. Carbohydr. Polym. 2017, 161, 118-139. [CrossRef] [PubMed]

88. Lara-Espinoza, C.; Carvajal-Millán, E.; Balandrán-Quintana, R.; López-Franco, Y.; Rascón-Chu, A. Pectin and Pectin-Based Composite Materials: Beyond Food Texture. Molecules 2018, 23, 942. [CrossRef] [PubMed]

89. Shivamathi, C.S.; Gunaseelan, S.; Soosai, M.R.; Vignesh, N.S.; Varalakshmi, P.; Kumar, R.S.; Karthikumar, S.; Kumar, R.V.; Baskar, R.; Rigby, S.P.; et al. Process Optimization and Characterization of Pectin Derived from Underexploited Pineapple Peel Biowaste as a Value-Added Product. Food Hydrocoll. 2022, 123, 107141. [CrossRef]

90. Lucarini, M.; Durazzo, A.; Bernini, R.; Campo, M.; Vita, C.; Souto, E.B.; Lombardi-Boccia, G.; Ramadan, M.F.; Santini, A.; Romani, A. Fruit Wastes as a Valuable Source of Value-Added Compounds: A Collaborative Perspective. Molecules 2021, $26,6338$. [CrossRef]

91. Wongkaew, M.; Chaimongkol, P.; Leksawasdi, N.; Jantanasakulwong, K.; Rachtanapun, P.; Seesuriyachan, P.; Phimolsiripol, Y.; Chaiyaso, T.; Ruksiriwanich, W.; Jantrawut, P.; et al. Mango Peel Pectin: Recovery, Functionality and Sustainable Uses. Polymers 2021, 13, 3898. [CrossRef] [PubMed]

92. Marić, M.; Grassino, A.N.; Zhu, Z.; Barba, F.J.; Brnčić, M.; Rimac Brnčić, S. An Overview of the Traditional and Innovative Approaches for Pectin Extraction from Plant Food Wastes and By-Products: Ultrasound-, Microwaves-, and Enzyme-Assisted Extraction. Trends Food Sci. Technol. 2018, 76, 28-37. [CrossRef]

93. Nasrollahzadeh, M.; Sajjadi, M.; Iravani, S.; Varma, R.S. Starch, Cellulose, Pectin, Gum, Alginate, Chitin and Chitosan Derived (Nano)Materials for Sustainable Water Treatment: A Review. Carbohydr. Polym. 2021, 251, 116986. [CrossRef] [PubMed]

94. Mohd Rasidek, N.A.; Mad Nordin, M.F.; Tokuyama, H.; Nagatsu, Y.; Mili, N.; Zaini, A.S.; Idham, Z.; Che Yunus, M.A. Subcritical Water-Based Pectin from Banana Peels (Musa Paradisiaca Cv.Tanduk) as a Natural Gelation Agent. Mater. Today Proc. 2021, 47, 1329-1335. [CrossRef]

95. Shishir, M.R.I.; Karim, N.; Gowd, V.; Xie, J.; Zheng, X.; Chen, W. Pectin-Chitosan Conjugated Nanoliposome as a Promising Delivery System for Neohesperidin: Characterization, Release Behavior, Cellular Uptake, and Antioxidant Property. Food Hydrocoll. 2019, 95, 432-444. [CrossRef]

96. Joshi, N.; Rawat, K.; Bohidar, H.B. PH and Ionic Strength Induced Complex Coacervation of Pectin and Gelatin A. Food Hydrocoll. 2018, 74, 132-138. [CrossRef]

97. Liu, J.; Zhou, H.; Tan, Y.; Mundo, J.L.M.; Mcclements, D.J. Comparison of Plant-Based Emulsifier Performance in Water-in-Oil-inWater Emulsions: Soy Protein Isolate, Pectin and Gum Arabic. J. Food Eng. 2021, 307, 110625. [CrossRef]

98. Liang, X.; Cao, K.; Li, W.; Li, X.; McClements, D.J.; Hu, K. Tannic Acid-Fortified Zein-Pectin Nanoparticles: Stability, Properties, Antioxidant Activity, and in Vitro Digestion. Food Res. Int. 2021, 145, 110425. [CrossRef] [PubMed]

99. Munarin, F.; Tanzi, M.C.; Petrini, P. Advances in Biomedical Applications of Pectin Gels. Int. J. Biol. Macromol. 2012, 51, 681-689. [CrossRef] [PubMed]

100. Martău, G.A.; Mihai, M.; Vodnar, D.C. The Use of Chitosan, Alginate, and Pectin in the Biomedical and Food SectorBiocompatibility, Bioadhesiveness, and Biodegradability. Polymers 2019, 11, 1837. [CrossRef] [PubMed]

101. Zhexenbay, N.; Akhmetsadykova, S.; Nabiyeva, Z.; Kizatova, M.; Iskakova, G. Using Pectin as Heavy Metals Detoxification Agent to Reduce Environmental Contamination and Health Risks. Procedia Environ. Sci. Eng. Manag. 2020, 7, 551-562. 
102. FAO-Food and Agriculture Organization of the United Nations. The State of World Fisheries and Aquaculture 2020. In Sustainability in Action; FAO: Rome, Italy, 2020. [CrossRef]

103. Teixeira-Costa, B.E.; Andrade, C.T. Chitosan as a Valuable Biomolecule from Seafood Industry Waste in the Design of Green Food Packaging. Biomolecules 2021, 11, 1599. [CrossRef] [PubMed]

104. Ozogul, F.; Cagalj, M.; Šimat, V.; Ozogul, Y.; Tkaczewska, J.; Hassoun, A.; Kaddour, A.A.; Kuley, E.; Rathod, N.B.; Phadke, G.G. Recent Developments in Valorisation of Bioactive Ingredients in Discard/Seafood Processing by-Products. Trends Food Sci. Technol. 2021, 116, 559-582. [CrossRef]

105. Sady, S.; Błaszczyk, A.; Kozak, W.; Boryło, P.; Szindler, M. Quality Assessment of Innovative Chitosan-Based Biopolymers for Edible Food Packaging Applications. Food Packag. Shelf Life 2021, 30, 100756. [CrossRef]

106. Muxika, A.; Etxabide, A.; Uranga, J.; Guerrero, P.; de la Caba, K. Chitosan as a Bioactive Polymer: Processing, Properties and Applications. Int. J. Biol. Macromol. 2017, 105, 1358-1368. [CrossRef]

107. Mujtaba, M.; Morsi, R.E.; Kerch, G.; Elsabee, M.Z.; Kaya, M.; Labidi, J.; Khawar, K.M. Current Advancements in Chitosan-Based Film Production for Food Technology; A Review. Int. J. Biol. Macromol. 2019, 121, 889-904. [CrossRef] [PubMed]

108. Morin-Crini, N.; Lichtfouse, E.; Torri, G.; Crini, G. Applications of Chitosan in Food, Pharmaceuticals, Medicine, Cosmetics, Agriculture, Textiles, Pulp and Paper, Biotechnology, and Environmental Chemistry. Environ. Chem. Lett. 2019, 17, 1667-1692. [CrossRef]

109. Khayrova, A.; Lopatin, S.; Varlamov, V. Obtaining Chitin, Chitosan and Their Melanin Complexes from Insects. Int. J. Biol. Macromol. 2021, 167, 1319-1328. [CrossRef] [PubMed]

110. Philibert, T.; Lee, B.H.; Fabien, N. Current Status and New Perspectives on Chitin and Chitosan as Functional Biopolymers. Appl. Biochem. Biotechnol. 2017, 181, 1314-1337. [CrossRef]

111. Younes, I.; Rinaudo, M. Chitin and Chitosan Preparation from Marine Sources. Structure, Properties and Applications. Mar. Drugs 2015, 13, 1133-1174. [CrossRef]

112. Santos, V.P.; Marques, N.S.S.; Maia, P.C.S.V.; Lima, M.A.B.d.; Franco, L.D.O.; Campos-Takaki, G.M.D. Seafood Waste as Attractive Source of Chitin and Chitosan Production and Their Applications. Int. J. Mol. Sci. 2020, 21, 4290. [CrossRef] [PubMed]

113. Campos, E.; Branquinho, J.; Carreira, A.S.; Carvalho, A.; Coimbra, P.; Ferreira, P.; Gil, M.H. Designing Polymeric Microparticles for Biomedical and Industrial Applications. Eur. Polym. J. 2013, 49, 2005-2021. [CrossRef]

114. Liu, X.; Gu, X.; Sun, J.; Zhang, S. Preparation and Characterization of Chitosan Derivatives and Their Application as Flame Retardants in Thermoplastic Polyurethane. Carbohydr. Polym. 2017, 167, 356-363. [CrossRef]

115. Cazón, P.; Velazquez, G.; Ramírez, J.A.; Vázquez, M. Polysaccharide-Based Films and Coatings for Food Packaging: A Review. Food Hydrocoll. 2017, 68, 136-148. [CrossRef]

116. Costa, J.C.M.D.; Miki, K.S.L.; Ramos, A.D.S.; Teixeira-Costa, B.E. Development of Biodegradable Films Based on Purple Yam Starch/Chitosan for Food Application. Heliyon 2020, 6, 1-10. [CrossRef]

117. Sanchez-Salvador, J.L.; Balea, A.; Monte, M.C.; Negro, C.; Blanco, A. Chitosan Grafted/Cross-Linked with Biodegradable Polymers: A Review. Int. J. Biol. Macromol. 2021, 178, 325-343. [CrossRef]

118. Hiremani, V.D.; Khanapure, S.; Gasti, T.; Goudar, N.; Vootla, S.K.; Masti, S.P.; Malabadi, R.B.; Mudigoudra, B.S.; Chougale, R.B. Preparation and Physicochemical Assessment of Bioactive Films Based on Chitosan and Starchy Powder of White Turmeric Rhizomes (Curcuma Zedoaria) for Green Packaging Applications. Int. J. Biol. Macromol. 2021, 193, 2192-2201. [CrossRef]

119. Souza, V.G.L.; Pires, J.R.A.; Rodrigues, C.; Coelhoso, I.M.; Fernando, A.L. Chitosan Composites in Packaging Industry-Current Trends and Future Challenges. Polymers 2020, 12, 417. [CrossRef]

120. Duan, C.; Meng, X.; Meng, J.; Khan, M.I.H.; Dai, L.; Khan, A.; An, X.; Zhang, J.; Huq, T.; Ni, Y. Chitosan as A Preservative for Fruits and Vegetables: A Review on Chemistry and Antimicrobial Properties. J. Bioresour. Bioprod. 2019, 4, 11-21. [CrossRef]

121. Duan, B.; Huang, Y.; Lu, A.; Zhang, L. Recent Advances in Chitin Based Materials Constructed via Physical Methods. Prog. Polym. Sci. 2018, 82, 1-33. [CrossRef]

122. Oberlintner, A.; Bajić, M.; Kalčíková, G.; Likozar, B.; Novak, U. Biodegradability Study of Active Chitosan Biopolymer Films Enriched with Quercus Polyphenol Extract in Different Soil Types. Environ. Technol. Innov. 2021, 21, 101318. [CrossRef]

123. Fallacara, A.; Baldini, E.; Manfredini, S.; Vertuani, S. Hyaluronic Acid in the Third Millennium. Polymers 2018, 10, 701. [CrossRef] [PubMed]

124. Li, J.; Qiao, M.; Ji, Y.; Lin, L.; Zhang, X.; Linhardt, R.J. Chemical, Enzymatic and Biological Synthesis of Hyaluronic Acids. Int. J. Biol. Macromol. 2020, 152, 199-206. [CrossRef] [PubMed]

125. Flores-Méndez, D.A.; Ramos-Ibarra, J.R.; Toriz, G.; Arriola-Guevara, E.; Guatemala-Morales, G.; Corona-González, R.I. Bored Coffee Beans for Production of Hyaluronic Acid by Streptococcus Zooepidemicus. Fermentation 2021, 7, 121. [CrossRef]

126. Boeriu, C.G.; Springer, J.; Kooy, F.K.; van den Broek, L.A.M.; Eggink, G. Production Methods for Hyaluronan. Int. J. Carbohydr. Chem. 2013, 2013, 1-14. [CrossRef]

127. Worldwide Hyaluronic Acid Distributors. Available online: https:/ / contox.com.br/9-marcas-de-acidos-hialuronicos-vendidasno-brasil/\#google_vignette (accessed on 27 August 2021).

128. Murado, M.A.; Montemayor, M.I.; Cabo, M.L.; Vázquez, J.A.; González, M.P. Optimization of Extraction and Purification Process of Hyaluronic Acid from Fish Eyeball. Food Bioprod. Process. 2012, 90, 491-498. [CrossRef]

129. Amagai, I.; Tashiro, Y.; Ogawa, H. Improvement of the Extraction Procedure for Hyaluronan from Fish Eyeball and the Molecular Characterization. Fish. Sci. 2009, 75, 805-810. [CrossRef] 
130. Gherezghiher, T.; Koss, M.C.; Nordquist, R.E.; Wilkinson, C.P. Analysis of Vitreous and Aqueous Levels of Hyaluronic Acid: Application of High-Performance Liquid Chromatography. Exp. Eye Res. 1987, 45, 347-349. [CrossRef]

131. Kang, D.Y.; Kim, W.S.; Heo, I.S.; Park, Y.H.; Lee, S. Extraction of Hyaluronic Acid (HA) from Rooster Comb and Characterization Using Flow Field-Flow Fractionation (FlFFF) Coupled with Multiangle Light Scattering (MALS). J. Sep. Sci. 2010, 33, $3530-3536$. [CrossRef] [PubMed]

132. Abdallah, M.M.; Fernández, N.; Matias, A.A.; Bronze, M.D.R. Hyaluronic Acid and Chondroitin Sulfate from Marine and Terrestrial Sources: Extraction and Purification Methods. Carbohydr. Polym. 2020, 243, 116441. [CrossRef] [PubMed]

133. Rosa, C.S.D.; Tovar, A.F.; Mourão, P.; Pereira, R.; Barreto, P.; Beirão, L.H. Purification and Characterization of Hyaluronic Acid from Chicken Combs. Ciênc. Rural 2012, 42, 1682-1687. [CrossRef]

134. Tiwari, S.; Bahadur, P. Modified Hyaluronic Acid Based Materials for Biomedical Applications. Int. J. Biol. Macromol. 2019, 121, 556-571. [CrossRef] [PubMed]

135. Crijns, H.; Vanheule, V.; Proost, P. Targeting Chemokine-Glycosaminoglycan Interactions to Inhibit Inflammation. Front. Immunol. 2020, 11, 483. [CrossRef] [PubMed]

136. Trombino, S.; Servidio, C.; Curcio, F.; Cassano, R. Strategies for Hyaluronic Acid-Based Hydrogel Design in Drug Delivery. Pharmaceutics 2019, 11, 407. [CrossRef] [PubMed] 